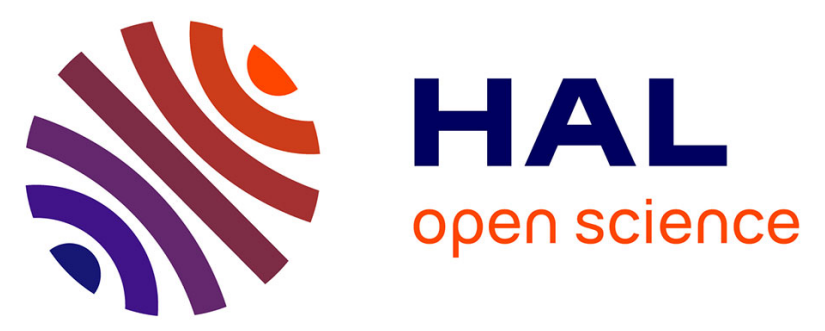

\title{
Exploring the drivers of vascular plant richness at very fine spatial scale in sub-Mediterranean limestone grasslands (Central Apennines, Italy)
}

Goffredo Filibeck, Marta G. Sperandii, Manuele Bazzichetto, Leone D. Mancini, Francesco Rossini, Laura Cancellieri

\section{To cite this version:}

Goffredo Filibeck, Marta G. Sperandii, Manuele Bazzichetto, Leone D. Mancini, Francesco Rossini, et al.. Exploring the drivers of vascular plant richness at very fine spatial scale in sub-Mediterranean limestone grasslands (Central Apennines, Italy). Biodiversity and Conservation, 2019, 28 (10), pp.27012725. 10.1007/s10531-019-01788-7 . hal-02181402

HAL Id: hal-02181402

https://hal-univ-rennes1.archives-ouvertes.fr/hal-02181402

Submitted on 13 Sep 2019

HAL is a multi-disciplinary open access archive for the deposit and dissemination of scientific research documents, whether they are published or not. The documents may come from teaching and research institutions in France or abroad, or from public or private research centers.
L'archive ouverte pluridisciplinaire HAL, est destinée au dépôt et à la diffusion de documents scientifiques de niveau recherche, publiés ou non, émanant des établissements d'enseignement et de recherche français ou étrangers, des laboratoires publics ou privés. 
1 Goffredo Filibeck ${ }^{1 *}$, Marta G. Sperandii ${ }^{2}$, Manuele Bazzichetto ${ }^{3}$, Leone D. Mancini ${ }^{1}$, Francesco Rossini ${ }^{1}$,

2 Laura Cancellieri ${ }^{1}$

4 Exploring the drivers of vascular plant richness at very fine spatial scale in sub-Mediterranean limestone grasslands (Central Apennines, Italy)

${ }^{1}$ Department of Agricultural and Forest Sciences (DAFNE), University of Tuscia, I-01100 Viterbo, Italy

${ }^{2}$ Department of Sciences, University of Roma Tre, I-00146 Rome, Italy

${ }^{3}$ UMR CNRS 6553 EcoBio, University of Rennes 1, 263 Avenue du Gal Leclerc, CS 74205, 35042 Rennes

10 CEDEX, France

$11 *$ *Corresponding author: filibeck@unitus.it, tel. +390761357215

13 Abstract

14 Secondary dry grasslands in Europe can host high levels of vascular plant richness at small spatial scales.

15 However, in Southern Europe their biodiversity patterns are largely unexplored. In this work, we aim at: i)

16 estimating plant species richness patterns at very fine scales in montane dry grasslands, on limestone bedrock, in Abruzzo Lazio \& Molise National Park (Central Apennines, Italy); ii) assessing the most important physical and edaphic drivers of biodiversity patterns at multiple plot sizes. We used randomly

19 placed nested-plot series where we measured alpha-diversity at three different plot sizes $\left(1 \mathrm{~m}^{2}, 0.1 \mathrm{~m}^{2}\right.$ and $0.01 \mathrm{~m}^{2}$ ) and within-plot beta-diversity (as expressed by the slope of the species-area curve across plot

21 sizes). Variable selection was performed by means of Random Forests. Relationships between selected variables and diversity measures were then assessed using Regression Trees, Linear and Generalized Linear

23 Models. Overall, results pointed to topographically-controlled edaphic factors (soil pH and silt fraction) as 24 the main drivers positively influencing alpha-diversity at all spatial scales, with a positive effect of rock cover and slope inclination at smaller spatial grains. Beta-diversity was positively influenced by rock cover. We suggest that high-pH, steep and/or rocky sites feature higher species richness because they lack 
competitive grass species. Our results are in agreement with previous works underlining the importance of less productive habitats for the conservation of secondary grassland biodiversity.

\section{Keywords}

Dry grasslands, Diversity metrics, Multi-scale approach, Soil properties, Species-area relationship, Topographical gradients

\section{Introduction}

Fine-scale species richness (species density or alpha-diversity) of vascular plants, i.e. the number of species occurring in fixed-area plots of small size (usually $\leq 100 \mathrm{~m}^{2}$ ), and the quest for its environmental determinants have been the subject of important studies and considerable discussion by plant ecologists (reviewed e.g. by Grace 1999). A considerable number of such works focused on European secondary grasslands (e.g. Grime 1973; Al-Mufti et al. 1977; van der Maarel and Sykes, 1993; Pärtel and Zobel 1999; Bennie et al. 2006; Löbel et al. 2006; Turtureanu et al. 2014; Reitalu et al. 2014; Palpurina et al. 2015; Güler et al. 2016). These are semi-natural habitats originated and maintained by disturbance such as livestock grazing, in areas that would be otherwise covered by forest vegetation; however, they are not man-made ecosystems, as livestock disturbance replaces the grazing and browsing by wild prehistoric megaherbivores and by extant ungulates (Pärtel et al. 2005; Feurdean et al. 2018). European secondary grasslands, and especially "dry" grasslands (i.e. those growing on free-draining substrates such as limestone), are of outstanding ecological value since they are among the most diverse plant communities in the world at plot sizes <100 m² (Pärtel et al. 2005; Wilson et al. 2012; Chytrý et al. 2015; Roleček et al. 2014). Moreover, they are an essential part of the cultural landscape of the continent, often resulting from millennia of lowintensity land-use (Poschlod and Wallis DeVries, 2002; Dengler et al., 2014; Feurdean et al. 2018); they host a high proportion of Europe's endemic plants (Habel et al. 2013); and act as a network of "interglacial

51 refugia" for Pleistocene (ice-age) steppic species (Hájková et al. 2011; Kajtoch et al. 2016; Cancellieri et al. 2017b). European secondary grasslands are currently threatened by grazing abandonment, conversion into cropland, afforestation and transformation into "improved" grasslands (Dolek and Geyer 2002; Habel et al. 

secondary grasslands are the subject of protection schemes at national (e.g. Kleijn and Sutherland 2003; Knop et al. 2006) and EU level (European Union, 1992).

In this framework, understanding the relationships between variability in species richness and environmental gradients is essential in order to develop management strategies in semi-natural habitats and limit biodiversity losses (Pärtel et al. 2005; Palpurina et al. 2015). However, such relationships are still not well known (Habel et al. 2013; Dengler et al. 2014; Palpurina et al. 2015), and different studies often found different strength and sign of a given environmental factor. In some instances, this can be due to non-linear relationships, as demonstrated by Chytrý et al. (2007) and Palpurina et al. (2017) for pH and by Fraser et al. (2015) for productivity. At the same time, scale-related issues may frequently explain the wide range of richness-environment relationships reported in the literature for semi-natural grasslands (Auestad et al. 2008): the effect and importance of any environmental factor can be different between very fine scales (e.g. $\leq 1 \mathrm{~m}^{2}$ ) and larger plot sizes (e.g. $100 \mathrm{~m}^{2}$ ), or between alpha- and beta-diversity (de Bello et al. 2007; Auestad et al. 2008; Polyakova et al. 2016). Indeed, biodiversity has many different facets that carry complementary information, so it is important to take into account different diversity metrics, or several spatial scales of the same measurement (e.g. Chiarucci et al. 2011; Pavoine and Bonsall 2011; Dengler et al. 2014). Moreover, from many geographic regions even descriptive information on grassland biodiversity patterns, such as the mean species richness or the most frequent taxa, are still lacking - especially for very fine spatial scales such as $1 \mathrm{~m}^{2}$ or smaller (Dengler 2009). This is even more so in Southern European landscapes, as they are less studied than their Central European counterparts (Apostolova et al. 2014). Although richness patterns at very fine spatial scales $\left(\leq 1 \mathrm{~m}^{2}\right)$ have to be collected and interpreted with caution because of many potential pitfalls (Gotelli and Colwell 2001; Palmer et al. 2008), these are the scales at which - in herbaceous vegetation - plant individuals interact with each other and build up ecosystem functioning and services (Grime 1998; Wellstein et al. 2014; Borer et al. 2014). In addition, using plots $\leq 1 \mathrm{~m}^{2}$ ensures that the sampling units are small in relation to the spatial scale of variation in topography and soil heterogeneity (Grime 1973). 
In the Italian Peninsula, extensive surveys of dry grassland biodiversity patterns and their edaphic drivers at

81 spatial grains $\leq 1 \mathrm{~m}^{2}$ are lacking: the only paper we are aware of, that analyzed richness patterns and 82 edaphic variables at fine scales (Maccherini 2006), was focused on a very small study area (cf. also Wellstein et al. 2014; Chelli et al. 2017). Nevertheless, the large areas of secondary grasslands in the Apennines chain (the mountain range forming the backbone of the Italian peninsula) are extremely interesting, because of considerable climatic and edaphic gradients (Primi et al. 2016), biogeographical position (e.g. Rosati et al. 2010; Blasi et al. 2012), conservation values (e.g. Manzi 2012; Primi et al. 2016; Cancellieri et al. 2017b) and a long history of sheep grazing and transhumance (Barker et al. 1991; Brown et al. 2013).

The present paper thus aims at analysing fine-scale diversity patterns and drivers from a network of secondary dry grasslands within the Central Apennine Mountains. We focused on the karst plateaux of the upper-montane bioclimatic belt: these habitats are characterized by a high topographical heterogeneity at micro- and meso-scale, thus featuring steep gradients of the potential controlling variables for species richness. We used randomized nested plots of three different sizes (0.01-0.1-1 $\left.\mathrm{m}^{2}\right)$ to answer the following questions: i) what are the levels and patterns of very fine-scale species richness at multiple spatial grains (alpha-diversity)? ii) what are the patterns of spatial turnover of species across the considered spatial grains (within-plot beta-diversity)? iii) what are the main environmental drivers of these diversity metrics, and do they vary between spatial scales?

\section{Methods}

\section{Study area}

101 Data were gathered within the "Abruzzo Lazio e Molise" National Park, in the Central Apennine mountains,

102 Italy $\left(41^{\circ} 48^{\prime} \mathrm{N}, 13^{\circ} 50^{\prime} \mathrm{E}\right)$. This protected area was designated in 1922 because it was the last refuge for both 103 the Marsican brown bear (Ursus arctos ssp. marsicanus) and the Apennine chamois (Rupicapra pyrenaica 104 ssp. ornata); at the same time, this area was until the 1950's one of the most important centers in Italy for 105 transhumant shepherding (Sievert 1999). The Park's flora comprises $>2,000$ species, including $>30$ taxa 106 endemic to the Central Apennine mountains (Conti and Bartolucci 2015); most of the Park's grasslands 
correspond to ecosystem types protected under the EU Habitats Directive (Primi et al. 2016). Five patches

108 of secondary dry grassland were chosen as study sites, for a total area of c. 500 ha (Fig. 1; additional

109 information are given in Online Resource 1). Their elevation ranges between c. 1350-1750 m a.s.l. and they

110 thus belong to the upper-montane phytoclimatic belt of the Apennines (Gerdol et al. 2008). All the studied

111 grassland patches are very similar: they lie on Mesozoic limestone bedrock (Bigi et al. 1986) and are located

112 in large bowl-shaped depressions, hosting in turn a system of different smaller landforms (see photos in

113 Online Resource 1) originated by complex interactions between karst, tectonic and glacial processes (Bigi et

114 al., 1986; Galadini and Messina 1990; Cinque et al. 1990). Such micro- and meso-scale landforms include

115 shallow dolines, sinkholes, hillocks, rocky outcrops, karren, etc. Because of karst hydrology, no surface

116 water bodies occur. The grassland patches are surrounded by beech (Fagus sylvatica) forest, which is

117 considered the potential vegetation of the area (Filibeck et al. 2015). Within the considered elevation belt,

118 dominant species in the Park's grasslands include Avenula praetutiana, Bromus erectus, Festuca

119 circummediterranea, Koeleria lobata and Phleum ambiguum on shallow to medium-depth soils; while on

120 deep soils (e.g. in karst hollows) Agrostis capillaris, Festuca microphylla and Nardus stricta often prevail

121 (Bruno and Bazzichelli, 1966). No phtyosociological studies targeted the study sites; however, relatively

122 similar habitats in neighbouring areas were described by Lucchese et al. (1995), Blasi et al. (1998) and Di

123 Pietro et al. (2005).

124 The local climate can be defined as sub-Mediterranean (Filibeck et al., 2015): it features high annual precipitation (c. 1,200-1,500 $\mathrm{mm} / \mathrm{yr}$ ), with a rainfall maximum in autumn and a very sharp drop in summer.

126 This precipitation regime leads to significant drought stress, especially for grassland plants, during July and 127 August (Catorci et al. 2012; Primi et al. 2016). Average annual temperature is between $6-8^{\circ} \mathrm{C}$; winters are 128 characterized by marked frost and abundant snowfall (see Filibeck et al. 2015, for climate diagrams and 129 details).

130 In the study area, secondary grasslands are maintained by grazing. Transhumant sheep grazing was widely 131 practiced until the 1950's, when ovine farming started to decrease for socio-economic reasons; sheep 132 stocking rate is nowadays drastically lower than in the early twentieth century (Manzi 2012). The decrease 133 of sheep husbandry has resulted in a steep increase in cattle and horse farming; such animals are usually 
135 of summer drought, mowing has never been a large-scale management system in the region (Manzi 1990),

136 and is currently not practiced at any of our study sites.

\section{Data collection}

139 Data were collected in early summer in 2013 and 2014. Sampling design was based on a grid of $300 \times 300 \mathrm{~m}$

140 cells, overlaid on the National Park area, with one random point selected within each cell (tessellation 141 stratified sampling: see e.g. Barabesi et al. 2012; Chiarucci et al. 2012). The five grassland clearings to be 142 investigated were chosen a priori, following field reconnaissance and inspection of detailed geological maps 143 that showed they had comparable features. All the random points falling within the five selected grassland 144 patches were retained, resulting in a total of 50 points (Fig. 1). At each GPS-located point (hereafter 145 "sampling point"), vascular plants were surveyed using a nested-plot series based on the design proposed 146 by Dengler (2009), as modified by Cancellieri et al. (2017a): one $1 \mathrm{~m}^{2}$ squared plot was centred on the 147 random point, and oriented N-S; two $0.1 \mathrm{~m}^{2}$ subplots were placed at the NE and SW corners of the $1 \mathrm{~m}^{2}$ 148 plot, and two $0.01 \mathrm{~m}^{2}$ subplots were placed within each of the $0.1 \mathrm{~m}^{2}$ plots (i.e., there are four $0.01 \mathrm{~m}^{2}$ 149 subplots at each sampling point) (Fig. 2 and Online Resource 1). The rationale for sampling a higher 150 number of subplots of smaller areas within each nested-plot series is twofold (Dengler 2009): i) it allows to 151 better account for the micro-environmental heterogeneity contained within the largest plot; ii) it allows the 152 use of mean species richness values within each nested series, thus liberating the resulting species-area 153 curve from stochasticity. Moreover, while species counts often do not follow a normal distribution, 154 averaging alpha-diversity values among sub-plots leads to normally distributed data (e.g. Quinn and Keough 155 2002).

156 Each nested-plot series was precisely delimited in the field by means of a plastic frame, and was surveyed 157 by at least two people to reduce inter-observer variability (e.g. Morrison 2015). For each plot and subplot, 158 we listed all vascular plant species (presence/absence data only), following the "shoot presence" criterion: 159 that is, a species is recorded as present if the vertical projection of any above-ground part of an individual 160 falls within the plot (Cancellieri et al. 2017a). Plant specimens that could not be identified in the field were 
161 collected and determined in the laboratory. Identification was mostly based on Pignatti (1982); plant names

162 were subsequently standardized following Conti et al. (2005). Given the still poorly-known taxonomy and 163 distribution of the genus Festuca in Italy, and considering that this taxon is one of the main builders of the 164 local plant communities, all Festuca "species" within each nested-plot series were collected for 165 identification in the laboratory through leaf section, following Foggi and Rossi (1996) and Foggi et al. 166 (1999).

167 For each nested-plot series, the following environmental variables were measured at 1- $\mathrm{m}^{2} \mathrm{spatial}$ scale 168 (Tab. 1). Elevation was measured with a GPS receiver. Slope inclination was measured by a clinometer. Slope aspect was measured with a compass and used to calculate heat-load index (based on latitude, aspect and inclination) following eq. 2 in McCune and Keon (2002). Soil depth was measured at 5 random 171 points with a $65-\mathrm{cm}$ long iron rod (soils deeper than rod length were arbitrarily given a value of $65 \mathrm{~cm}$ ); the 172 median of the 5 measurements was used in the analyses. Percentage of stone and rock cover was visually 173 estimated. Land-form position was visually assessed as a categorical variable as follows: "hollow" 174 (indicating the flat or gently sloping position in concave morphologies such as the bottom of dolines, other 175 karst depressions or gullies), "hillside" (for the sloping sides of both meso- and macro-scale landforms), and 176 "hump" (for convex landforms such as hillocks, ridges or rocky outcrops). Soil samples were collected with a hand auger (Eijkelkamp, NL) from the upper 10-cm layer as a mixed sample from 3 randomly placed points within each $1 \mathrm{~m}^{2}$ plot, and subsequently air-dried and crushed to pass a 2-mm sieve. Soil $\mathrm{pH}$ was measured in water (soil-solution suspension of 1:2.5). Soil texture (clay, silt and sand fraction) was determined through the standard sedimentation techniques (Gee and Bauder 1986) adopting the ISSS dimensional 181 limits, without pre-treatment with $\mathrm{H}_{2} \mathrm{O}_{2}$. Soil organic matter was determined using Walkley-Black method. 182 The plot data are available in GrassPlot, the Database of Scale-Dependent Phytodiversity Patterns in 183 Palaearctic Grasslands (GIVD ID EU-00-003) (Dengler et al. 2018).

\section{Data analysis}

186 For each nested-plot series, the following diversity metrics were calculated from the collected data, to be 187 used as response variables in the statistical analysis: species richness of the whole $1 \mathrm{~m}^{2}$ plot (hereafter, " 1 
$\mathrm{m}^{2}$ alpha-diversity"); mean species richness of the two $0.1 \mathrm{~m}^{2}$ subplots (hereafter, "0.1 $\mathrm{m}^{2}$ alpha-diversity");

189 mean species richness of the four $0.01 \mathrm{~m}^{2}$ subplots (hereafter, "0.01 $\mathrm{m}^{2}$ alpha-diversity"); and "z-value", i.e.

190 the slope of the species-area relationship calculated from the three spatial scales at each nested-plot

191 series.

192 We assumed for the species-area curve the Arrhenius (1921) power function:

$$
S=c A^{z}
$$

and we calculated the z-values with linear regression in double-log space (e.g. Chiarucci et al. 2006), i.e. using the equation:

$$
\log S=\log c+z \log A
$$

197 (where $\mathrm{S}=$ number of species, $\mathrm{A}=$ plot size; $\mathrm{c}$ and $\mathrm{z}$ are the estimated parameters, i.e. the intercept at $\mathrm{A}=1$ 198 and the slope of the regression line, respectively).

199 Fitting of the species-area function was performed for each nested-plot series, using for the $0.1 \mathrm{~m}^{2}$ size the 200 mean richness values of the two subplots, and for the $0.01 \mathrm{~m}^{2}$ size the mean richness values of the four 201 subplots. The z-values of nested-plot series are useful for comparing the degree of spatial species turnover 202 between different ecological situations (e.g. Chiarucci et al. 2006; de Bello et al. 2007; Dengler 2008; 203 Turtureanu et al. 2014; Polyakova et al. 2016). They are a measure of beta-diversity (i.e. of the variation in 204 the identities of species between plots) at fine spatial scale, as the shape of the species area-curve reflects 205 the level of spatial homogeneity of species distribution and community composition (Storch 2016). Collinearity between the predictor variables, as well as the strength of the univariate relationships between each predictor variable and the diversity metrics, was preliminarily checked using pairwise Spearman correlations. We then excluded the percentage of sand from further analyses because by definition the three soil texture fractions sum up to 100 and, of the three texture components, sand exhibited the highest 210 degree of correlation with other predictor variables. Since the study area had been deliberately defined 211 within a specific elevation belt, and the range of altitudinal variation among plots was thus small, elevation 212 was not included in the analyses. One sampling point presented outlying values from soil analysis, leading 213 to suspect an error occurred in laboratory processing, and was excluded from statistical analysis on 214 diversity-environment relationships, that are thus based on $n=49$. 
215 We performed our main statistical analysis through Recursive Partitioning approaches ("Regression Trees" 216 and "Random Forests": Strobl et al. 2009a). Recursive Partitioning methods have many desirable properties 217 that make them attractive for the ecologist (De'ath and Fabricius 2000): they can successfully handle very 218 high number of predictors, are robust to multicollinearity, independent from any assumptions on the 219 distribution of errors and can successfully handle and reveal complex interactions and non-linear 220 relationships (Sandri and Zuccolotto 2006; Hapfelmeier and Ulm 2013).

221 As a first step, in order to identify the most relevant explanatory variables we used Random Forests (i.e. an ensemble method combining several Classification or Regression Trees), which several studies highlighted as an effective variable selection approach (Sandri and Zuccolotto 2006; Hapfelmeier and UIm 2013; Svitok et al. 2016). Random Forests were run using R package "party" (function "cforest": Hothorn et al., 2006b; Strobl et al. 2007; Strobl et al. 2008), as it implements conditional inference trees which are designed to reduce the bias that such tools otherwise have towards highly correlated variables (Strobl et al. 2008, 2009b). The number of "trees" in the "forests" was set to 1000 , while the number of randomly preselected predictor variables for each split was set to 3, following Strobl et al. (2009a). As Random Forests are, by definition, "random", repeating the process (i.e. re-running the algorithm) is recommended in order to ensure the robustness and stability of the model (Strobl et al. 2009a; Shih 2011). For this reason, for each of 231 the four response variables a Random Forest was run 10 times. For each Random Forest, a conditional measure of variable importance was computed for all predictors using function "varimp". We defined as "important" and retained for further analysis only those environmental variables which, in at least six out of the 10 Random Forest tries, featured positive values exceeding the absolute value of the most negative score (cf. Strobl et al. 2009a).

As a second step of analysis, individual Regression Trees were built for each response variable, including as predictors those environmental variables identified by the Random Forests as important for each biodiversity measure. Regression Trees have recently proven to be very effective in studying plant diversity 239 drivers (e.g. Chytrý et al. 2007; Palpurina et al. 2015; Svitok et al. 2016). We used them to identify the 240 environmental characteristics most strongly associated with each response variable, assess the sign of the 241 relationship, detect interactions among predictors and estimate the environmental thresholds for species 
richness (De'ath and Fabricius 2000; Strobl et al. 2009a). We performed Regression Tree analysis with package "party" in R (function "ctree", Hothorn et al. 2006a), implementing "Conditional Inference" Trees: these were preferred to the more classical approach, based on the "CART" algorithm, as the latter may be biased towards continuous predictors measured over large scales or categorical predictors with many categories (Hothorn et al. 2006a; Strobl et al. 2009a). Besides, "Conditional Inference" Trees, implementing a statistically robust stopping criterion, do not suffer from overfitting (Strobl et al. 2009a). The algorithm tests the global null hypothesis of independence between any of the input variables and the response; it stops if this hypothesis cannot be rejected, otherwise selects the input variable with strongest association to the response. This association is measured by a p-value corresponding to a test for the partial null hypothesis of a single input variable and the response. The stop criterion is by default based on multiplicity adjusted $p$-values (Bonferroni correction), but univariate $p$-values can be alternatively used. This approach ensures that the right sized "tree" is grown and no "pruning" or cross-validation is needed (Hothorn et al. 2006a).

Additionally, we assessed the strength of the relationship between the response variables and the selected predictors through Generalized Linear Models (GLM) and multiple Linear Models. Whenever two predictors (among those selected through the Random Forest output) were highly correlated with each other (i.e. had a Spearman correlation coefficient $>0.6$ ), we retained only the most biologically informative one. Since the explanatory variables are measured in different units, standardized regression coefficients (obtained by subtracting, from each observation, the variable mean and dividing by the standard deviation: e.g. Quinn and Keough 2002) were computed to allow comparison of the effect sizes on the response variable ; for Linear Models we standardized both explanatory and response variables, while for Generalized Linear Models we only transformed predictors. For $1 \mathrm{~m}^{2}$ alpha-diversity, a Poisson Generalized Linear Model was fitted, setting "log" as link function. Overdispersion was tested using R package "AER" (function “dispersiontest": Kleiber and Zeileis 2008). We used an adjusted Pseudo- $\mathrm{R}^{2}$ (Guisan and Zimmermann 2000) to quantify the improvement in the deviance explained by the model including the selected predictors over 267 the intercept-only model (R package "modEvA", function "Dsquared": Barbosa et al. 2016). For $0.1 \mathrm{~m}^{2}$ and $2680.01 \mathrm{~m}^{2}$ alpha-diversity, as they were obtained averaging the species counts among subplots of the same 
size within each nested series, we assumed a Gaussian distribution of errors: thus multiple Linear Models were fitted and adjusted- $R^{2}$ was used to quantify explained variability. Z-values were log-transformed

271 before model fitting in order to meet linear-model assumptions.

272 Finally, to help ecological interpretation of the richness patterns and elucidate their relationship with 273 floristic composition, a PCA (based on a correlation matrix) of the plot $\times$ species matrix was run, adding the $2741 \mathrm{~m}^{2}$ alpha-diversity as a covariate, in order to underline which taxa were associated with different levels of 275 species richness.

276 Note that in the results section we shall use $p$-values as a continuous measure of fit of the null hypothesis to the data, instead of using them for a "significant/non-significant" dichotomy (Wassertein and Lazar 2016; Greenland et al. 2016).

\section{Results}

281 Overall diversity

282 Across all 50 sampling points, a total of 198 vascular plant species were recorded; 64 species (32\% of the 283 total recorded flora) were found at only one nested series (singletons). Mean species richness per plot was $28410.3,18.5$ and 28.0 for $0.01 \mathrm{~m}^{2}, 0.1 \mathrm{~m}^{2}$ and $1 \mathrm{~m}^{2}$, respectively (Tab.2). The mean slope $(\mathrm{z})$ of the species285 area relationship was 0.238 (Tab.2); i.e., richness increased by c. 1.7 times, on average, with a ten-fold increase in plot area. The most frequent species (in terms of proportion of sampling plots where the taxon was recorded) are listed in Tab. 3. The full $1 \mathrm{~m}^{2}$-plot $\times$ species matrix (including the frequency values of all species) is provided as Online Resource 3.

\section{Diversity-environment relationships}

291 Descriptive statistics of the environmental variables are shown in Tab.1. Pairwise Spearman's correlation 292 matrix (Tab.4) highlighted that many predictor variables were correlated with each other: most notably, 293 soil $\mathrm{pH}$ was positively correlated with stone and rock cover $\left(r_{s}=0.64\right)$ and with slope inclination $\left(r_{s}=0.48\right)$, 294 and negatively correlated with soil depth $\left(r_{s}=-0.61\right)$; stone and rock cover was positively related to slope 295 inclination $\left(r_{s}=0.54\right)$. As for the relationships between predictor and dependent variables, species richness 
at $1 \mathrm{~m}^{2}$ spatial scale ( $1 \mathrm{~m}^{2}$ alpha-diversity) was positively correlated with silt $\%\left(r_{s}=0.38\right)$, soil $\mathrm{pH}\left(r_{s}=0.37\right)$

and stone and rock cover $\left(r_{s}=0.30\right)$. However, all these relationships became weaker moving to 0.1 and 0.01

$298 \mathrm{~m}^{2}$ spatial scales. The $z$-values were positively correlated with stone and rock cover $\left(r_{\mathrm{s}}=0.58\right)$; in addition,

299 they showed a positive correlation with slope inclination $\left(r_{s}=0.37\right)$ and a negative relationship with soil 300 depth $\left(r_{s}=-0.48\right)$.

301 In Tab. 5 it is reported, for each of the four response variables, how many times, out of the 10 Random Forest tries, each predictor variable turned out to be significant. Both soil $\mathrm{pH}$ and silt \% were found to be significant predictors across all 10 runs for all three alpha-diversity spatial scales. Stone and rock cover and slope inclination were stable outcomes for $1 \mathrm{~m}^{2}$ and $0.1 \mathrm{~m}^{2}$; soil depth and land-form position were constantly significant only at $1 \mathrm{~m}^{2}$ spatial scale. As for z-values, soil $\mathrm{pH}$ was never a significant predictor, while land form, stone and rock cover, inclination and soil depth were significant in all runs. Heat-load index was never significant for any of the dependent variables.

308 The Regression Tree for $1 \mathrm{~m}^{2}$ alpha-diversity identified a significant threshold value for $\mathrm{pH}$ at 6.4 , i.e. the 309 plots with soil pH smaller than this value hosted, on average, significantly lower richness. The model further partitioned the group of high-pH sites based on soil texture, showing that the maximum species richness is 311 attained at sites featuring simultaneously high $\mathrm{pH}$ values and high silt \% (fig. 3). However, as shown above, 312 within the study area soil pH is positively correlated with slope inclination and stone and rock cover, and 313 negatively correlated with soil depth; thus, high $\mathrm{pH}$ values can also indicate steep slopes or rocky humps 314 with shallow soil.

315 For $0.1 \mathrm{~m}^{2}$ and $0.01 \mathrm{~m}^{2}$ alpha-diversity, Regression Tree analysis performed with "ctree" default rules didn't 316 yield any statistically significant partition. If univariate p-values were used (see Methods) instead of the 317 stop criterion based on Bonferroni correction (cf. Nakagawa 2004), then the resulting tree for the 0.1- $\mathrm{m}^{2}$ 318 sub-plots highlighted the role of slope inclination and soil $\mathrm{pH}$ (and their interaction). Steeper slopes 319 (indicating also stony soils, as explained above) showed greater species richness at $0.1 \mathrm{~m}^{2}$ spatial scale. The 320 lowest richness was found when a low slope inclination was combined with a pH value lower than 6.2, 321 indicating flat bottoms of concave landforms with deep, sub-acid soils (fig. 4). As for the $0.01 \mathrm{~m}^{2}$ alpha322 diversity, no significant partitions were detected even after the Bonferroni correction was removed. 
In the Regression Tree for z-values, stone and rock cover was identified as a strongly significant predictor,

324 with two subsequent partitions based on the same variable (fig. 5), thus underlining a regular increase of the slope of the species-area curve with increasing soil rockiness, and showing that low z-values were consistently found when stone and rock cover was less than $3 \%$.

For the $1 \mathrm{~m}^{2}$ alpha-diversity GLM, the predictor variables selected on the basis of Random Forest output were soil $\mathrm{pH}$, land-form, silt \%, slope inclination, soil depth and stone and rock cover. However, as both soil depth and stone and rock cover were highly correlated with soil pH (Spearman's $r_{s}>0.6$ ), they were not included in the model. The inclusion of $\mathrm{pH}$ as quadratic term (based on a preliminary graphical exploration, that showed a slightly hump-shaped trend) did not improve significantly the fit of the models as checked via likelihood ratio test for the GLM and ANOVA for the Linear Models; therefore we retained only the firstorder term for $\mathrm{pH}$ in the final models. GLM results (Tab. 6) showed that $1 \mathrm{~m}^{2}$ alpha-diversity was positively associated with silt $\%$ (standardized coefficient $=0.13, p<0.001$ ), and was on average higher in "hump" landforms than in hollows and hillsides. Slope inclination and $\mathrm{pH}$ were positively, but very weakly, associated with $1 \mathrm{~m}^{2}$ alpha-diversity (stand. coeff. $=0.05, \mathrm{p}=0.1$, for both predictors); however, as soil $\mathrm{pH}$ was markedly correlated with two omitted variables, its parameter estimate may be biased. The adjusted Pseudo- $\mathrm{R}^{2}$ of the model was 0.53 (i.e. the predictors explained $53 \%$ of the deviance in $1 \mathrm{~m}^{2}$ alpha-diversity).

As for $0.1 \mathrm{~m}^{2}$ alpha-diversity, the predictor variables selected for fitting the Linear Model were: soil $\mathrm{pH}$, slope inclination, silt \%, clay \% and stone and rock cover. As stone and rock cover was highly correlated with soil $\mathrm{pH}\left(r_{s}>0.6\right)$, it was removed from the model. Silt fraction showed a positive relationship with 0.1 $\mathrm{m}^{2}$ alpha-diversity (stand. coeff. $=0.47, \mathrm{p}<0.001$ ); a smaller positive effect, with a high error, was showed by slope inclination (stand. coeff. $=0.23, \mathrm{p}=0.1$ ) and soil $\mathrm{pH}$ (stand. coeff. $=0.22, \mathrm{p}=0.1$ ); for this latter, the same caveats hold as in the $1 \mathrm{~m}^{2}$ model (Tab. 6). The model explained $31 \%$ of variability. $\mathrm{p}<0.01)$; a smaller positive effect was showed also by soil $\mathrm{pH}$, but with a high standard error and a large $\mathrm{p}$ value (stand. coeff. $=0.18 ; p=0.2$ ) (Tab. 6). The model explained only $13 \%$ of variability. 
Finally, z-values were modelled as a function of land-form position, stone and rock cover, slope inclination, and soil depth. Model results (Tab. 6) showed a strong positive effect (stand. coeff. $=0.63, p<0.001$ ) of stone 351 and rock cover. The model explained $47 \%$ of variability.

352 In the PCA of the $1-\mathrm{m}^{2}$ plots $\times$ species matrix, species richness was correlated with PC2 (loading $=-0.57$ ). 353 The correlation coefficients of the species on this factor, allowing to highlight the taxa that were consistently associated with either the richest or the poorest plots, are listed in Online Resource 2.

\section{Discussion}

\section{Overall diversity}

358 Especially at the finest spatial scales, mean and maximum species richness per plot ranked quite high within 359 the context of Palaearctic grasslands, supporting earlier hypothesis that S-European grasslands can host 360 high levels of alpha-diversity (Apostolova et al. 2014): for instance, our maximum of 20 vascular plant 361 species in $0.01 \mathrm{~m}^{2}$ quadrats is the second highest among all the Eurasian datasets reported by Dengler et al. 362 (2016) (cf. also Chytrý et al. 2015). At $1 \mathrm{~m}^{2}$ scale, the maximum richness value (41 species) was not 363 exceptionally high (cf. Merunková et al. 2012; Wilson et al. 2012), although still within the "upper range" at 364 European scale (Chytrý et al. 2015; Dengler et al. 2016). However, our data stem from a randomized 365 sampling design, while most datasets that contain or approach the European "richness records" originate from plots that were placed subjectively with the aim to record the most species-rich sites (e.g. Merunková

et al. 2012). Beta-diversity as expressed by z-values was within the range typically reported for dry grasslands in Europe, and our mean z-value (0.24) was very close to what found in many previous studies (see e.g. Baumann et al. 2016, and references therein).

The probabilistic sampling used in this study allowed to quantitatively define (Chiarucci 2007) the most common species within the landscapes studied (Tab. 3). Among grasses, the most frequent taxon was Festuca circummediterranea, followed by Poa alpina and Koeleria lobata, pointing to an interesting codominance of Mediterranean and Boreal geographic elements. Similarly, among forbs, the Apennine endemic Viola eugeniae turned out to be present in $2 / 3$ of the samples, but the most common species was Hieracium pilosella (found in $80 \%$ of the quadrats), a typical example of the European geographic element. 


\section{Diversity-environment relationship: alpha-diversity}

378 Soil $\mathrm{pH}$ and silt fraction were positively correlated with species richness at all spatial scales. Slope inclination, stone and rock cover and "hump" land-form were positively influencing species richness as well, but only at $1 \mathrm{~m}^{2}$ and/or $0.1 \mathrm{~m}^{2}$ spatial grains, and with weaker effect sizes.

381 There is a huge body of works on the positive (or unimodal) relationship between soil pH and plot-scale diversity in Eurasian grasslands (see references in: Chytrý et al. 2007; Palpurina et al. 2017), although in most studies the quadrat size was larger $\left(10-100 \mathrm{~m}^{2}\right)$ than in the present work (but see Grime 1973). This relationship has been explained assuming that during the glacial phases the acidophilous pool of species underwent a much higher extinction rate than the acidifuge contingent because of the unbalanced distribution of soil types across the ice-age biomes), thus leading to a smaller pool of acidophilous than calcicolous species in the present-day regional floras (Grime 1973; Grace 1999; Ewald 2003; Tyler 2003;

388 Chytrý et al. 2003).

389 However, since many of our environmental variables showed correlated gradients in the field (cf. Bennie et 390 al. 2006; Baumann et al. 2016), it is difficult to separate the role of pH per se from that of other 391 environmental variables. Sites with steep and rocky or shallow soils have necessarily high $\mathrm{pH}$ values because of the surfacing limestone material (e.g. Palpurina et al. 2017); on the other hand, because of the widespread calcareous bedrocks, in our study area low $\mathrm{pH}$ values are usually confined to concave landforms (hollows, dolines, bases of slopes), in turn typically associated with deep soils, low rock cover and low slope inclination. Such land-forms can host acid soils, in spite of the base-rich bedrock, mainly because they accumulate clayey and decarbonated soil through colluvial deposition and karstic processes (e.g. Calandra 1999); in addition, they may trap huge amounts of wind-blown siliceous materials such as Saharan quartz silt and volcanic ashes (Giraudi 1995; Sauro 2004), and/or host a thick snow cover, favoring podzolization 399 (Hiller et al. 2005). At the same time, dolines and hollows will receive more water and nutrients than 400 convex land-forms or steep slopes (Araya et al. 2011; Batori et al. 2017), host soil types with higher clay 401 fraction and higher available water content (Di Pietro et al. 2005), and undergo lower levels of natural 402 disturbance at micro-scale via summer drought, water run-off and erosion (Bennie et al. 2006). 
A large number of studies found that grassland species richness in Europe and N-America was reduced on

404 soils with high moisture and nutrients, while attained maximum values at sites with relatively dry, nutrient405 poor and shallow soils (reviews by Grace 1999 and by Keddy 2005; see also Bennie et al. 2006; Bonanomi et 406 al. 2006; Maccherini 2006; Moeslund et al. 2013b; Baumann et al. 2016; Filibeck et al. 2016; Kleinebecker et 407 al. 2018; Palpurina et al. 2019). Even in a different floristic kingdom, Cantero et al. (2003) found that in mountain grasslands in Argentina, species richness of $1-\mathrm{m}^{2}$ quadrats had a negative relationship with soil depth and available water, and a positive correlation with stone cover. This is consistent with the classical model of humped-back relationship between productivity and richness, usually explained assuming that in 411 very productive sites a few strong competitors will create closed canopies and accumulate litter, reducing 412 the amount of light reaching soil surface and outcompeting stress-tolerant species that have lower growth 413 rates (e.g. Al-Mufti et al. 1977; Janssens et al. 1998; Grytnes 2000; Stevens and Carson 2002; Pärtel et al. 414 2005; Kleinebecker et al. 2018; but see Šímová et al. 2013 for a review and empirical testing of some 415 alternative or concurrent explanations).

416 Thus, we surmise that, in our study area, the positive effect by soil pH on richness may partly be explained 417 with the different levels of stress controlled by the same topographical factors that influence soil $\mathrm{pH}$ 418 (Moeslund et al. 2013a): dry and steep land-forms may promote a higher species density because they 419 favor the coexistence of many small-sized species that colonize "gaps" and are not able to grow in more productive sites dominated by large, mat-forming and litter-accumulating species (Grubb 1976; Bennie et al. 2006; Wellstein et al. 2013, 2014).

This hypothesis is supported by the PCA of the plot $\times$ species matrix (Online Resource 2), revealing that the poorer plots were characterized by perennial grasses known for their typical "competitive" characteristics (Grime 1973) such as Agrostis capillaris and Festuca microphylla. The former is a patch-forming species, capable of establishing a dense leaf canopy and assuming dominance due to its ability for rapid lateral spread (Grime et al. 2007); the latter belongs to the group of fescues with extra-vaginal branching strategy 427 (Pignatti 1982; for a definition of this trait see e.g. Stace et al. 1992), a character leading to the 428 development of expanded tussocks and mats. Notably, both A. capillaris and F. microphylla are also well 429 known for being bound to acidic to sub-acid soils throughout their geographic range (e.g. Pignatti 1982; 
Grime et al. 2007) and, within the pedo-climatic context of the Apennines, to fine-earth deep soils (e.g.

431 Bruno and Bazzichelli 1966; Pignatti 1982; Blasi et al. 1998). Thus, in our study area, the observed effect of $432 \mathrm{pH}$ on species richness might actually be caused by vegetation structure patterns led by these two grasses, 433 unable to establish at high-pH and dry sites. Consistently, among the species significantly associated (in the 434 PCA) with the poorer plots, there were some herbs characterized by creeping growth-forms (Potentilla rigoana, Veronica serpyllifolia), a strategy that allows to exploit the shaded micro-habitat under the grass canopy or to colonize the surface of the thick litter (Grime 1998). On the other hand, the perennial grass most significantly associated in the PCA with the high-richness plots was Festuca circummediterranea, a 438 fescue that can only develop into isolated tufts with a reduced lateral spread, because of intra-vaginal 439 shoot system (e.g. Pignatti 1982). Indeed, the other species correlated with the richer plots included either opportunistic annuals (e.g. Arenaria serpyllifolia, Cynosurus echinatus, Geranium molle, Medicago lupulina, 441 Trifolium scabrum) that may fill the "gaps" between the perennial grasses, or typically stress- resistant, 442 slow-growing plants (e.g. the CAM species Sedum acre).

443 Somewhat similar conclusions were drawn by a study on plant traits and assembly rules in another area of 444 the Central Apennines (Wellstein et al. 2013, 2014), showing that Sesleria nitida, a grass capable of forming 445 high-density carpets, was the main factor suppressing species coexistence at extremely fine spatial scale $446\left(0.0025 \mathrm{~m}^{2}\right)-$ but only on $\mathrm{N}$-facing slopes, because on the dryer S-facing slopes it built single, isolated tussocks leaving large spaces available to other species. However, since in the present study we didn't collect data on species cover or traits, further work is necessary to confirm our hypotheses.

449 Finally, an interesting problem concerns silt fraction: this predictor showed a positive effect on species 450 richness, even at the $0.01 \mathrm{~m}^{2}$ grain, and it was the only significant environmental variable to be 451 uncorrelated with the $\mathrm{pH}$ gradient. The strong role of this predictor was quite unexpected and is not easy to 452 explain. Only a small number of studies on grassland diversity analyzed soil texture, and even these often 453 failed to find a correlation with species richness (e.g. Turtureanu et al. 2014). The results by Stohlgreen et 454 al. (1999) and Cousins and Eriksson (2002), showing a positive effect of silty soils on species richness, can't 455 be compared with our observations because of their plot sizes being much larger and their pedo-climatic 456 context very different. Moreover, we acknowledge that the soil texture data used in our study were 
obtained without the prior destruction of soil organic matter (SOM) with $\mathrm{H}_{2} \mathrm{O}_{2}$, leading to possible overestimation of silt and underestimation of clay fraction because of silt-sized micro-aggregates made up of SOM-clay complexes (Jensen et al. 2017). However, silty soils are generally better drained than clayey soils, and extremely silt-rich soils may be scarcely fertile as they do not show any structural arrangement because of lack of the binding properties provided by clay (e.g. Thompson 1952). In a phytosociological study performed in a neighboring area, silt fraction was found to be higher in the xerophytic, sparse grasslands of steep slopes, than in the mesic, dense communities of karst hollows (Di Pietro et al. 2005). Thus, the effect of silt might point once again to a negative correlation - within the study region - between species richness and biomass or competition, in turn controlled by topographic-hydrological gradients.

\section{Diversity-environment relationship: spatial scales}

We found that the relative importance of some predictors varied with plot size. This was already shown by previous studies dealing with multiple-scale sampling in grasslands (e.g. Auestad et al. 2008; Polyakova et al. 2016). It has been suggested that at extremely fine scales the availability of nutrients will influence the identity of the dominant species, in turn influencing richness; while at larger plot sizes, factors controlling richness via habitat heterogeneity will prevail (Auestad et al. 2008). Although we only had a small range of plot sizes, this may explain while stone and rock cover (a proxy of habitat heterogeneity) had a relevant effect only at $1 \mathrm{~m}^{2}$.

The overall explanatory power of the predictor variables became weaker with decreasing plot size. This is not unexpected, because very small spatial scales are unavoidably associated with the increasing effects of factors other than the physical variables, such as plant individual number and size (Palmer et al. 2008; Storch 2016), stochastic disturbance and diaspore availability (Zobel et al. 2000), and fine-scale plant interactions (Wellstein et al. 2014). Moreover, environmental variables were measured at the scale of the largest plot, so they might not be representative of the micro-habitat variability between the subplots. 
A high z-value (slope) of the species-area curve implies that there is a low mean number of individuals per

484 species (Storch 2016), i.e. each species occurs with scattered individuals leading to a high spatial 485 heterogeneity of the vegetation. This can be in some cases a result of physical habitat heterogeneity. Indeed, we found that z-values were positively correlated with stone and rock cover and with "humps", and negatively correlated with soil depth: this can be explained as rocky and shallow soils give rise to a "rough" microtopography; while the flat, deep soils of the doline bottoms are rather homogeneous. Although stone and rock cover can also influence z-values via a trivial mechanism (i.e., on very rocky soils there is a higher chance that the subplots of the smallest size will fall on a completely bare surface, thus inflating the steepness of the species-area curve), in our study area rock-free soils are usually found only in concave land-forms, i.e. at sites with high $\mathrm{pH}$ and deep soils: hence, there is some overlapping between sites that curtail species richness (alpha-diversity) and sites featuring a low turnover of species between spatial scales (beta-diversity). Our results are thus consistent with Chiarucci et al. (2006), who found a negative relationship between z-values and productivity in Tuscany and in Germany. Polyakova et al. (2016), in primary steppe grasslands in S-Siberia, found a strong positive effect on z-values of soil roughness at microscale. In contrast, both Turtureanu et al. (2014) (in secondary grasslands in Romania) and Baumann et al. (2016) (in high-elevation grasslands in the Italian Alps) found that their measured environmental predictors explained little of the variability in z-values. However, comparisons of z-values between different studies have to be interpreted very cautiously, as the results will depend on the size of the plots used (Chiarucci et al. 2006).

\section{Conclusions}

The importance ranking and effect size of the environmental variables were partly different across alphadiversity spatial scales or between alpha- and beta-diversity; nevertheless, the sites with acid and deep soils had on average lower levels of all the diversity measures, while maximum alpha- and beta-diversity were usually attained at sites with neutro-basic and shallow soils, often on steep or rocky land-forms. These relationships seem to be mediated by competition: at the low-diversity sites, species coexistence is probably suppressed by a small number of carpet-forming species, in turn bound to topographically- 
controlled "islands" of acidic or deep soils. Further studies will be necessary in the Apennine grasslands to

511 confirm this explanation.

512 However, the observed patterns point to the importance of the less productive and dryer sites for the 513 conservation of secondary grassland plant diversity, as underlined by many previous works (e.g. Grime 514 1973; Moore et al. 1989; Wassen et al. 2005; Bennie et al. 2006; Cingolani et al. 2010; Filibeck et al. 2016; 515 Kleinebecker et al. 2018; Palpurina et al. 2019). In the Apennine mountains, these oligotrophic habitats 516 seem to be not (yet) significantly threatened by atmospheric nitrogen deposition (Bonanomi et al. 2006; 517 Nogueira et al. 2017; but see Ochoa-Hueso et al. 2017), a factor heavily impacting some C- and N-European 518 grasslands (e.g. Stevens et al. 2010). They may be nevertheless at risk because of grazing abandonment 519 (Bonanomi et al. 2006): many sectors of the Apennines have witnessed the development of a closed 520 woodland in a very short time (Bracchetti et al. 2012; Amici et al. 2013). Moreover, in many European and 521 Mediterranean landscapes, shrub and tree colonization seems to be hindered in land-forms with deep 522 clayey soils and to take place preferentially on shallow or rocky soils, probably because of reduced 523 competition by grasses and larger availability of suitable microsites (Grove and Rackham 2001: 57; Rackham 524 2006: 201-202; Pärtel and Helm 2007). This might lead to a proportionally larger loss of those grassland 525 types that host the highest levels of alpha- and beta-diversity.

\section{Authors' contribution}

528 G.F. and L.C. conceived the study and the sampling methodology; L.C. coordinated field work; L.D.M., 529 M.G.S. and G.F. participated in field sampling; L.C. revised critical vascular plants; F.R. supervised soil 530 analysis; M.G.S., M.B. and G.F. performed data analysis; G.F. supervised the overall work and led the 531 writing; all authors discussed the results and contributed to text editing.

\section{Acknowledgements}

534 We are grateful to Abruzzo Lazio \& Molise National Park agency for having authorized field work (special 535 thanks to C. Gentile and C. Sulli for scientific advice and field support), G. Ubertini for laboratory analysis, S. 536 Soliveres and M. Brandi for advice on recursive partitioning, S. Maccherini and M. Marignani for useful 
537 discussions and two anonymous reviewers for their detailed comments on the manuscript. G.F. and F.R.

538 carried out the research in the frame of the MIUR (Italian Ministry for Education, University and Research)

539 initiative "Department of excellence" (Law 232/2016).

541 Online resource 1: Geographic features and photographs of the study sites

542 Online resource 2: Results of the correlation PCA from the plots $\times$ species matrix

543 Online resource 3: Matrix of $1 \mathrm{~m}^{2}$ plots $\times$ species matrix

\section{References}

546 Al-Mufti MM, Sydes CL, Furness SB, Grime JP, Band SR (1977) Quantitative analysis of shoot phenology and 547 dominance in herbaceous vegetation. J Ecol 65:759-791

548 Amici V, Santi E, Filibeck G, Diekmann M, Geri F, Landi S, Scoppola A, Chiarucci A (2013) Influence of 549 secondary forest succession on plant diversity patterns in a Mediterranean landscape. J Biogeogr 40: $550 \quad 2335-2347$.

551 Apostolova I, Dengler J, Di Pietro R, Gavilán RG, Tsiripidis I (2014) Dry grasslands of Southern Europe: 552 syntaxonomy, management and conservation. Hacquetia 13:1-14

553 Araya YN, Silvertown J, Gowing DJ, McConway KJ, Peter Linder H, Midgley G (2011) A fundamental, eco554 hydrological basis for niche segregation in plant communities. New Phytologist 189:253-258

555 Arrhenius O (1921) Species and area. J Ecol 9:95-99

556 Auestad I, Rydgren K, Økland RH (2008) Scale-dependence of vegetation-environment relationships in semi557 natural grasslands. J Veg Sci 19:139-148

558 Barabesi L, Franceschi S, Marcheselli M (2012) Properties of design-based estimation under stratified 559 spatial sampling with application to canopy coverage estimation. The Annals of Applied Statistics 6:210$560 \quad 228$ 
561 Barbosa AM, Brown JA, Jimenez-Valverde A, Real R (2016) modEvA: Model Evaluation and Analysis. R 562 package version 1.3.2. https://CRAN.R-project.org/package=modEvA

563 Barker G, Grant A, Beavitt P, Christie N, Giorgi J, Hoare P, Leggio T, Migliavacca M (1991) Ancient and 564 modern pastoralism in central Italy: an interdisciplinary study in the Cicolano mountains. Papers of the $565 \quad$ British School at Rome 59:15-88

566 Bátori Z, Vojtkó A, Farkas T, Szabó A, Havadtői K, Vojtkó AE, Tölgyesi C, Cseh V, ErdősL, Maák I, Keppel G 567 (2017) Large- and small -scale environmental factors drive distributions of cool-adapted plants in karstic 568 microrefugia. Ann Bot 119:301-30

569 Baumann E, Weiser F, Chiarucci A, Jentsch A, Dengler J (2016) Diversity and functional composition of 570 alpine grasslands along an elevational transect in the Gran Paradiso National Park (NW Italy). Tuexenia $571 \quad 36: 337-358$

572 Bennie J, Hill MO, Baxter R, Huntley B (2006) Influence of slope and aspect on long-term vegetation change 573 in British chalk grasslands. Journal of Ecology 94:355-368

574 Bigi G, Colacicchi R, Damiani AV, D'Andrea M, Pannuzi L, Parotto M, Praturlon A, Sirna G (1986) Carta 575 Geologica del Parco Nazionale d'Abruzzo. Ente Autonomo Parco Nazionale d'Abruzzo, Pescasseroli.

576 Blasi C, Capotorti G, Fortini P (1998) On the vegetation series in the northern sector of the Simbruini 577 mountains (Central Apennines). Fitosociologia 35:85-102

578 Blasi C, Facioni L, Burrascano S, Del Vico E, Tilia A, Rosati L (2012) Submediterranean dry grasslands along 579 the Tyrrhenian sector of central Italy: Synecology, syndynamics and syntaxonomy. Plant Biosystems 146: $580 \quad 266-290$

581 Bonanomi G, Caporaso S, Allegrezza M (2006) Short-term effects of nitrogen enrichment, litter removal and 582 cutting on a Mediterranean grassland. Acta Oecologica 30:419-425

583 Borer ET, Seabloom EW, Gruner DS, Harpole WS, Hillebrand H et al (2014) Herbivores and nutrients control 584 grassland plant diversity via light limitation. Nature 508:517-520 
Bracchetti L, Carotenuto L, Catorci A (2012) Land-cover changes in a remote area of central Apennines (Italy) and management directions. Landsc Urb Plann 104:157-170

Brown AG, Hatton J, Selby KA, Leng M, Christie N (2013) Multi-proxy study of Holocene environmental change and human activity in the Central Apennine Mountains, Italy. J Quatern Sci 28:71-82

Bruno F, Bazzichelli G (1966) Note illustrative alla carta della vegetazione del Parco Nazionale d'Abruzzo. Annali di Botanica (Roma) 28:739-778

Burrascano S, Chytrý M, Kuemmerle T, Giarrizzo E, Luyssaert S, Sabatini FM, Blasi C (2016) Current European policies are unlikely to jointly foster carbon sequestration and protect biodiversity. Biol Conserv 201:370-376

Cancelllieri L, Mancini LD, Sperandii MG, Filibeck G (2017a) In and out: effects of shoot- vs. rooted-presence sampling methods on plant diversity measures in mountain grasslands. Ecological Indicators 72:315-321

Cancelllieri L, Sperandii MG, Filibeck G (2017b) First record of the steppic relict Astragalus exscapus L. 598 subsp. exscapus in the Apennines (Abruzzo, Italy), and biogeographic implications. Plant Biosystems $599 \quad 151: 944-948$

600 Cantero JJ, Liira J, Cisneros JM, Gonzalez J, Nuñez C, Petryna L, Cholaky C, Zobel M (2003) Species richness, 601 alien species and plant traits in Central Argentine mountain grasslands. J Veg Sci 14:129-136

602 Catorci A, Ottaviani G, Kosić IV, Cesaretti S. (2012). Effect of spatial and temporal patterns of stress and 603 disturbance intensities in a sub-Mediterranean grassland. Plant Biosystems 146:352-367

604 Chelli S, Wellstein C, Campetella G, Canullo R, Tonin R, Zerbe S, Gerdol R (2017) Climate change response of 605 vegetation across climatic zones in Italy. Climate Research 71:249-262

606 Chiarucci A, Viciani D, Winter C, Diekmann M (2006) Effects of productivity on species-area curves in 607 herbaceous vegetation: evidence from experimental and observational data. Oikos 115:475-483 
608 Chiarucci, A. (2007) To sample or not to sample? That is the question... for the vegetation scientist. Folia 609 Geobotanica 42:209-216

610 Chiarucci A, Bacaro G, Scheiner SM (2011) Old and new challenges in using species diversity for assessing 611 biodiversity. Phil Trans R Soc B 366:2426-2437

612 Chiarucci A, Bacaro G, Filibeck G, Landi S, Maccherini S, Scoppola A (2012) Scale dependence of plant 613 species richness in a network of protected areas. Biodivers Conserv 21:503-516

614 Chytrý M, Tichý L, Roleček J (2003) Local and regional patterns of species richness in central European 615 vegetation types along the pH/calcium gradient. Folia Geobotanica 38:429-442.

616 Chytrý M, Danihelka J, Ermakov N, Hájek M, Hájková P, Kočí M, Kubešová S, Lustyk P, Otýpková Z, Popov D, 617 Roleček J, Řezníčková M, Šmarda P, Valachovič M (2007) Plant species richness in continental southern 618 Siberia: effects of $\mathrm{pH}$ and climate in the context of the species pool hypothesis. Global Ecol Biogeogr $619 \quad 16: 668-678$

620 Chytrý M, Dražil T, Hájek M, Kalníková V, Preislerová Z, Šibík J, Ujházy K, Axmanová I, Bernátová D, Blanar D, 621 Dančak M, Dřevojan P, Fajmon K, Galvanek D, Hajkova P, Herben T, Hrivnak R, Janeček S, Janišova M, 622 Jiraska Š, Kliment J, Kochjarova , Lepš J, Leskovjanska A, Merunkova K, Mladek J, Slezak M, Šeffer J, 623 Šefferova V, Škodova I, Uhliřova J, Ujhazyova M, Vymazalova M (2015) The most species-rich plant 624 communities in the Czech Republic and Slovakia (with new world records). Preslia 87:217-278

625 Cingolani AM, Vaieretti MV, Gurvich DE, Giorgis MA, Cabido M (2010) Predicting alpha, beta and gamma 626 plant diversity from physiognomic and physical indicators as a tool for ecosystem monitoring. Biological 627 Conservation 143:2570-2577

628 Cinque A, Liccardo C, Palma B, Pappalardo L, Rosskopf C, Sepe C (1990) Le tracce glaciali nel Parco 629 Nazionale d'Abruzzo (Appennino centrale): nota preliminare. Geografia Fisica Dinamica Quaternaria $630 \quad 13: 121-133$

631 Conti F, Abbate G, Alessandrini A, Blasi C (2005) An Annotated Checklist of the Italian Vascular Flora. 632 Palombi, Roma 
633 Conti F, Bartolucci F (2015) The vascular flora of the National Park of Abruzzo, Lazio and Molise (Central 634 Italy). Springer, $\mathrm{CH}$.

635 Cousins SA, Eriksson O (2002) The influence of management history and habitat on plant species richness in 636 a rural hemiboreal landscape, Sweden. Landscape Ecology 17:517-529

637 De'ath G, Fabricius KE (2000) Classification and regression trees: a powerful yet simple technique for 638 ecological data analysis. Ecology 81:3178-3192

639 de Bello F, Lepš J, Sebastià MT (2007) Grazing effects on the species-area relationship: variation along a 640 climatic gradient in NE Spain. J Veg Sci 18:25-34

641 Dengler J, (2008) Pitfalls in small-scale species-area sampling and analysis. Folia Geobotanica 43:269-287

642 Dengler J (2009) A flexible multi-scale approach for standardised recording of plant species richness 643 patterns. Ecological Indicators 9:1169-1178

644 Dengler J, Janišová M, Török P, Wellstein C (2014) Biodiversity of Palaearctic grasslands: a synthesis. Agric 645 Ecosyst Environ 182:1-14

646 Dengler J, Biurrun I, Apostolova I, Baumann E, Becker T et al (2016) Scale-dependent plant diversity in 647 Palaearctic grasslands: a comparative overview. Bulletin of the Eurasian Dry Grassland Group 31:12-26

648 Dengler J, Wagner V, Dembicz I, García-Mijangos I, Naqinezhad A et al (2018) GrassPlot-a database of 649 multi-scale plant diversity in Palaearctic grasslands. Phytocoenologia 48:331-347

650 Di Pietro R, De Santis A, Fortini P (2005) A geobotanical survey on acidophilous grasslands in the Abruzzo, 651 Lazio and Molise National Park (Central Italy). Lazaroa 26:115-137

652 Dolek M, Geyer A (2002) Conserving biodiversity on calcareous grasslands in the Franconian Jura by grazing: 653 a comprehensive approach. Biological Conservation 104:351-360

654 European Union (1992) Council Directive 92/43/EEC of 21 may 1992 on the conservation of natural habitats 655 and of wild fauna and flora. https://eur-lex.europa.eu/legal-content/EN/TXT/?uri=celex\%3A31992L0043. 656 Accessed 15 September 2018 
Ewald J (2003) The calcareous riddle: why are there so many calciphilous species in the Central European

658 flora? Folia Geobotanica 38:357-366

659 Feurdean A, Ruprecht E, Molnár Z, Hutchinson SM, Hickler T (2018): Biodiversity-rich European grasslands:

660 Ancient, forgotten ecosystems. Biological Conservation 228:224-232

661 Filibeck G, Adams J, Brunetti M, Di Filippo A, Rosati L, Scoppola A, Piovesan G (2015) Tree ring ecological 662 signal is consistent with floristic composition and plant indicator values in Mediterranean Fagus sylvatica 663 forests. Journal of Ecology 103:1580-1593

664 Filibeck G, Petrella P, Cornelini P (2016) All ecosystems look messy, but some more so than others: a case665 study on the management and acceptance of Mediterranean urban grasslands. Urban Forestry \& Urban 666 Greening 15:32-39

667 Foggi B, Rossi G (1996) A survey of the genus Festuca L. (Poaceae) in Italy. I. The species of the summit flora 668 in the Tuscan-Emilian Apennines and Apuan Alps. Willdenowia 26:1-33

669 Foggi B, Rossi G, Signorini MA (1999): The Festuca violacea aggregate (Poaceae) in the Alps and Apennines 670 (central-southern Europe). Can J Bot 77:989-1013

671 Fraser LH, Pither J, Jentsch A, Sternberg M, Zobel M et al (2015) Worldwide evidence of a unimodal 672 relationship between productivity and plant species richness. Science 349:302-305

673 Galadini F, Messina P (1990) Osservazioni su un deposito a blocchi al margine SW della conca di 674 Pescasseroli (Italia centrale). II Quaternario 3:23-30

675 Gee GW, Bauder JW (1986) Particle-size Analysis. In: Methods of Soil Analysis, Part 1. Soil Science Society of 676 America, Madison:383-411

677 Gerdol R, Stanisci A, Tomaselli M, Fazzini M (2008) La vegetazione delle montagne italiane. Club Alpino 678 Italiano, Roma

679 Giraudi C (1995) Sedimenti eolici, variazioni climatiche ed influenza antropica: considerazioni su alcune 680 piane intermontane dell'Appennino Abruzzese. II Quaternario 8:211-216 
681 Gotelli NJ, Colwell RK (2001) Quantifying biodiversity: procedures and pitfalls in the measurement and 682 comparison of species richness. Ecology Letters 4:379-391

683 Grace JB (1999) The factors controlling species density in herbaceous plant communities: an assessment. 684 Perspectives in Plant Ecology, Evolution and Systematics 2:1-28

685 Greenland S, Senn SJ, Rothman KJ, Carlin JC, Poole C, Goodman SN, Altman DG (2016) Statistical tests, 686 confidence intervals, and power: A guide to misinterpretations. European Journal of Epidemiology $687 \quad 31: 337-50$

688 Grime JP (1973) Control of species density in herbaceous vegetation. Journal of Environmental 689 Management 1:151-167

690 Grime JP (1998) Benefits of plant diversity to ecosystems: immediate, filter and founder effects. Journal of 691 Ecology 86:902-910

692 Grime JP, Hodgson JG, Hunt R (2007) Comparative plant ecology: a functional approach to common British 693 species. Springer

694 Grove AT, Rackham O (2001) The nature of Mediterranean Europe: an ecological history. Yale University 695 Press, Yale

696 Grubb PJ (1976) A theoretical background to the conservation of ecologically distinct groups of annuals and 697 biennials in the chalk grassland ecosystem. Biological Conservation 10(1):53-76

698 Grytnes JA (2000) Fine-scale vascular plant species richness in different alpine vegetation types: 699 relationships with biomass and cover. J Veg Sci 11:87-92

700 Guisan A, Zimmermann NE (2000) Predictive habitat distribution models in ecology. Ecological $701 \quad$ Modelling 135:147-186

702 Güler B, Jentsch A, Bartha S, Bloor JMG, Campetella G, Canullo R, Házi J, Kreyling J, Pottier J, Szabó G, 703 Terziyska T, Ugurlu E, Wellstein C, Zimmermann Z, Dengler J (2016) How plot shape and dispersion affect 
704 plant species richness counts: implications for sampling design and rarefaction analyses. J Veg Sci 27:692$705 \quad 703$

706 Habel JC, Dengler J, Janišová M, Török P, Wellstein C, Wiezik M (2013) European grassland ecosystems: 707 threatened hotspots of biodiversity. Biodivers Conserv 22:2131-2138

708 Hájková P, Roleček J, Hájek M, Horsák M, Fajmon K, Polák M, Jamrichová E (2011) Prehistoric origin of the 709 extremely species-rich semi-dry grasslands in the Bílé Karpaty Mts (Czech Republic and Slovakia). Preslia $710 \quad 83: 185-204$

711 Hapfelmeier A, Ulm K (2013) A new variable selection approach using random forests. Computational 712 Statistics \& Data Analysis 60:50-69

713 Hiller B, Nuebel A, Broll G, Holtmeier FK (2005) Snowbeds on silicate rocks in the Upper Engadine (Central 714 Alps, Switzerland)-pedogenesis and interactions among soil, vegetation, and snow cover. Arctic, 715 Antarctic, and Alpine Research 37(4):465-476

716 Hothorn T, Hornik K, Zeileis A (2006a) Unbiased Recursive Partitioning: A Conditional Inference Framework. 717 Journal of Computational and Graphical Statistics 15:651-674

718 Hothorn T, Buehlmann P, Dudoit S, Molinaro A, Van Der Laan M (2006b) Survival Ensembles. Biostatistics $719 \quad 7: 355-373$

720 Janssens F, Peeters A, Tallowin JRB, Bakker JP, Bekker RM, Fillat F, Oomes MJM (1998) Relationship 721 between soil chemical factors and grassland diversity. Plant and Soil 202:69-78

722 Jensen JL, Schjønning P, Watts CW, Christensen BT, Munkholm $\amalg$ (2017) Soil texture analysis revisited: 723 Removal of organic matter matters more than ever. PLoS ONE 12(5): e0178039

724 Kajtoch Ł, Cieślak E, Varga Z, Paul W, Mazur MA, Sramkó G, Kubisz D (2016) Phylogeographic patterns of 725 steppe species in Eastern Central Europe: a review and the implications for conservation. Biodiv Conserv $726 \quad 25: 2309-2339$ 
727 Keddy P (2005) Putting the Plants Back into Plant Ecology: Six Pragmatic Models for Understanding and 728 Conserving Plant Diversity. Annals of Botany 96:177-189

729 Kleijn D, Sutherland WJ (2003) How effective are European agri-environment schemes in conserving and 730 promoting biodiversity? J Appl Ecol 40:947-969

731 Kleiber C, Zeileis A (2008) Applied Econometrics with R. New York: Springer-Verlag.

732 Kleinebecker T, Busch V, Hölzel N, Hamer U, Schäfer D, Prati D, Fischer M, Hemp A, Lauterbach R, Klaus VH 733 (2018) And the winner is....! A test of simple predictors of plant species richness in agricultural grasslands. $734 \quad$ Ecological Indicators 87:296-301

735 Knop EVA, Kleijn D, Herzog F, Schmid B (2006) Effectiveness of the Swiss agri-environment scheme in promoting biodiversity. J Appl Ecol 43:120-127

737 Kuzemko AA, Steinbauer MJ, Becker T, Didukh YP, Dolnik C, Jeschke M, Naqinezhad A, Ugurlu E, Vassilev K, 738 Dengler J (2016) Patterns and drivers of phytodiversity in steppe grasslands of Central Podolia (Ukraine). 739 Biodivers Conserv 25:2233-2250

740 Löbel S, Dengler J, Hobohm C (2006) Species richness of vascular plants, bryophytes and lichens in dry 741 grasslands: The effects of environment, landscape structure and competition. Folia Geobotanica 41:377$742 \quad 393$

743 Lucchese F, Persia G, Pignatti S (1995) I prati a Bromus erectus Hudson dell'Appennino Laziale. $744 \quad$ Fitosociologia 30:145-180

745 Maccherini S (2006) Factors associated with species richness in a remnant calcareous grassland. Grassland $746 \quad$ Science 52:181-184

747 Manzi A (1990) La gestione dei pascoli montani in Abruzzo e la Società delle Erbe Seconde di Pescasseroli 748 ed Opi. Archivio Botanico 66:129-142

749 Manzi A (2012) Storia dell'ambiente nell'Appennino centrale: la trasformazione della natura in Abruzzo 750 dall'ultima glaciazione ai giorni nostri. Chieti: Meta. 
751 McCune B, Keon D (2002) Equations for potential annual direct incident radiation and heat load. J Veg Sci $752 \quad 13: 603-606$

753 Merunková K, Preislerová Z, Chytrý M (2012) White Carpathian grasslands: can local ecological factors 754 explain their extraordinary species richness? Preslia 84: 311-325

755 Moeslund JE, Arge L, Bøcher PK, Dalgaard T, Svenning JC (2013a) Topography as a driver of local terrestrial 756 vascular plant diversity patterns. Nord J Bot 31:129-144

757 Moeslund JE, Arge L, Bøcher PK, Dalgaard T, Odgaard MV et al (2013b) Topographically controlled soil 758 moisture is the primary driver of local vegetation patterns across a lowland region. Ecosphere 4:1-26

Moore DRJ, Keddy PA, Gaudet CL, Wisheu IC (1989) Conservation of wetlands: do infertile wetlands deserve a higher priority? Biological Conservation 47:203-217

761 Morrison LW (2015) Observer error in vegetation surveys: a review. Journal of Plant Ecology 9: 367-379.

762 Nakagawa S (2004) A farewell to Bonferroni: the problems of low statistical power and publication bias.

763 Behavioral Ecology 15:1044-1045

764 Nogueira C, Bugalho MN, Pereira JS, Caldeira MC (2017) Extended autumn drought, but not nitrogen 765 deposition, affects the diversity and productivity of a Mediterranean grassland. Environmental and 766 Experimental Botany 138:99-108

767 Ochoa-Hueso R., Munzi S, Alonso R, Arróniz-Crespo M, Avila A, et al. (2017) Ecological impacts of 768 atmospheric pollution and interactions with climate change in terrestrial ecosystems of the 769 Mediterranean Basin: Current research and future directions. Environmental Pollution 227:194-206

770 Palmer MW, McGlinn DJ, Fridley JD (2008) Artifacts and artifictions in biodiversity research. Folia 771 Geobotanica 43:245-257

772 Palpurina S, Chytrý M, Tzonev R, Danihelka J, Axmanová I, Merunková K, Duchoň M, Karakiev T (2015) 773 Patterns of fine-scale plant species richness in dry grasslands across the eastern Balkan Peninsula. Acta 774 Oecologica 63:36-46 
Palpurina S, Wagner V, von Wehrden H, Hájek M, Horsák M et al (2017) The relationship between plant species richness and soil pH vanishes with increasing aridity across Eurasian dry grasslands. Global Ecology and Biogeography 26:425-434

Palpurina S, Chytrý M, Hölzel N, Tichý L, Wagner V et al 2019 The type of nutrient limitation affects the plant species richness-productivity relationship: Evidence from dry grasslands across Eurasia. Journal of Ecology, in press. doi.org/10.1111/1365-2745.13084

Pärtel M, Bruun HH, Sammul M (2005) Biodiversity in temperate European grasslands: origin and conservation. Grassland Science in Europe 10:1-14

Pärtel M, Helm A (2007) Invasion of woody species into temperate grasslands: relationship with abiotic and biotic soil resource heterogeneity. Journal of Vegetation Science 18:63-70

Pärtel M, Zobel M (1999) Small-scale plant species richness in calcareous grasslands determined by the species pool, community age and shoot density. Ecography 22:153-159

Pavoine S, Bonsall MB (2011) Measuring biodiversity to explain community assembly: a unified approach. Biol. Rev. 86:792-812

Pignatti S (1982) Flora d'Italia. Edagricole, Bologna.

Polyakova MA, Dembicz I, Becker T, Becker U, Demina ON, Ermakov N, Filibeck G, Guarino R, Janišová M, Jaunatre R, Kozub L, Steinbauer MJ, Suzuki K, Dengler J (2016) Scale- and taxon-dependent patterns of plant diversity in steppes of Khakassia, South Siberia (Russia). Biodivers Conserv 25:2251-2273

Poschlod P, WallisDeVries MF (2002) The historical and socioeconomic perspective of calcareous grasslands - lessons from the distant and recent past. Biological Conservation 104:361-376

Primi R, Filibeck G, Amici A, Bückle C, Cancellieri L, Di Filippo A, Gentile C, Guglielmino A, Latini R, Mancini LD, Mensing SA, Rossi CM, Rossini F, Scoppola A, Sulli C, Venanzi R, Ronchi B, Piovesan G (2016) From Landsat to leafhoppers: a multidisciplinary approach for sustainable stocking assessment and ecological monitoring in mountain grasslands. Agric Ecosyst Environm 234:118-133 
Quinn GP, Keough MJ (2002) Experimental Design and data Analysis for Biologists. Cambridge University

800 Press, Cambridge

801 Rackham O (2006) Woodlands. Harper Collins, London

802 Reitalu T, Helm A, Pärtel M, Bengtsson K, Gerhold P, Rosén E, Takkis, Znamenskiy S, Prentice HC (2014)

803 Determinants of fine-scale plant diversity in dry calcareous grasslands within the Baltic Sea region. Agric 804 Ecosyst Environm 182:59-68

805 Roleček J, Čornej II, Tokarjuk AI (2014) Understanding the extreme species richness of semi-dry grasslands 806 in east-central Europe: a comparative approach. Preslia 86:13-34

807 Rosati L, Filibeck G, De Lorenzis A, Lattanzi E, Surbera F, Fascetti S, Blasi C. (2010) The forest vegetation of 808 the Alburni Mts. (Cilento N. P., Campania, Southern Italy): Syntaxonomy and phytogeography $809 \quad$ Fitosociologia, 47:17-55

810 Sandri M, Zuccolotto P (2006) Variable selection using random forests. In: Zani S, Cerioli A, Riani M, Vichi M 811 (Eds.) Data Analysis, Classification and the Forward Search. In: Studies in Classification, Data Analysis, and 812 Knowledge Organization. Springer, Berlin, Heidelberg

813 Sauro U (2004) Altopiani carsici. In: IGM, "Atlante dei Tipi Geografici”, pp. 306-310

814 Sievert J (1999) Abruzzo National Park: Land of Dreams. Environment and History 5: 293-307.

815 Šímová I, Li YM, Storch D (2013) Relationship between species richness and productivity in plants: the role 816 of sampling effect, heterogeneity and species pool. Journal of Ecology 101:161-170

817 Stace CA, Al-Bermani AKKA, Wilkinson MJ (1992) The distinction between the Festuca ovina L. and Festuca 818 rubra L. aggregates in the British Isles. Watsonia 19:107-112

819 Stevens MHH, Carson WP (2002) Resource quantity, not resource heterogeneity, maintains plant diversity. 820 Ecology Letters 5:420-426

821 Stevens CJ, Duprè C, Dorland E, Gaudnik C, Gowing DJ, et al. (2010). Nitrogen deposition threatens species 822 richness of grasslands across Europe. Environmental Pollution 158:2940-2945 
823 Stohlgren TJ, Schell LD, Heuvel BV (1999). How grazing and soil quality affect native and exotic plant 824 diversity in Rocky Mountain grasslands. Ecological Applications 9:45-64

825 Storch D (2016) The theory of the nested species-area relationship: geometric foundations of biodiversity 826 scaling. J Veg Sci 27:880-891

827 Strobl C, Boulesteix AL, Zeileis A, Hothorn T (2007) Bias in Random Forest Variable Importance Measures: 828 Illustrations, Sources and a Solution. BMC Bioinformatics 8:25

829 Strobl C, Boulesteix AL, Kneib T, Augustin T, Zeileis A (2008) Conditional variable importance for random 830 forests. BMC Bioinformatics 9:307

831 Strobl C, Malley J, Tutz G (2009a) An introduction to recursive partitioning: rationale, application, and 832 characteristics of classification and regression trees, bagging, and random forests. Psychological Methods $833 \quad 14: 323-348$

834 Strobl C, Hothorn T, Zeileis A (2009b) Party on! A new, conditional variable importance measure for random 835 forests available in party package. The R Journal. 1/2:14-17

836 Svitok M, Hrivnák R, Kochjarová J, Otahel'ová H, Pal'ove-Balang P (2016) Environmental thresholds and 837 predictors of macrophyte species richness in aquatic habitats in central Europe. Folia Geobotanica $838 \quad 51: 227-238$

839 Thompson LM (1952) Soils And Soil Fertility. McGraw-Hill, New York

840 Turtureanu PD, Palpurina S, Becker T, Dolnik C, Ruprecht E, Sutcliffe LME, Szabó A, Dengler J (2014) Scale841 and taxon-dependent biodiversity patterns of dry grassland vegetation in Transylvania. Agric Ecosyst 842 Environ 182:15-24

843 Tyler G (2003) Some ecophysiological and historical approaches to species richness and calcicole/calcifuge 844 behaviour - contribution to a debate. Folia Geobotanica 38:419-428

845 van der Maarel E, Sykes MT (1993) Small-scale plant species turnover in a limestone grassland: the carousel 846 model and some comments on the niche concept. J Veg Sci 4:179-188 
847 Wassen MJ, Venterink HO, Lapshina ED, Tanneberger F (2005) Endangered plants persist under phosphorus $848 \quad$ limitation. Nature 437:547-550

849 Wasserstein RL, Lazar NA (2016) The ASA's Statement on p-Values: Context, Process, and Purpose. The $850 \quad$ American Statistician 70:129-133

851 Wellstein C, Chelli S, Campetella G, Bartha S, Galiè M, Spada F, Canullo R (2013) Intraspecific phenotypic 852 variability of plant functional traits in contrasting mountain grasslands habitats. Biodiv Cons 22:2353-2374

853 Wellstein C, Campetella G, Spada F, Chelli S, Mucina L, Canullo R, Bartha S (2014) Context-dependent 854 assembly rules and the role of dominating grasses in semi-natural abandoned sub-Mediterranean 855 grasslands. Agric Ecosyst Environ 182:113-122

856 Wilson JB, Peet RK, Dengler J, Pärtel M (2012) Plant species richness: the world records. J Veg Sci 23:796$857 \quad 802$

858 Zobel M, Otsus M, Liira J, Moora M, Möls T (2000) Is small-scale species richness limited by seed availability 859 or microsite availability? Ecology 81:3274-3282 


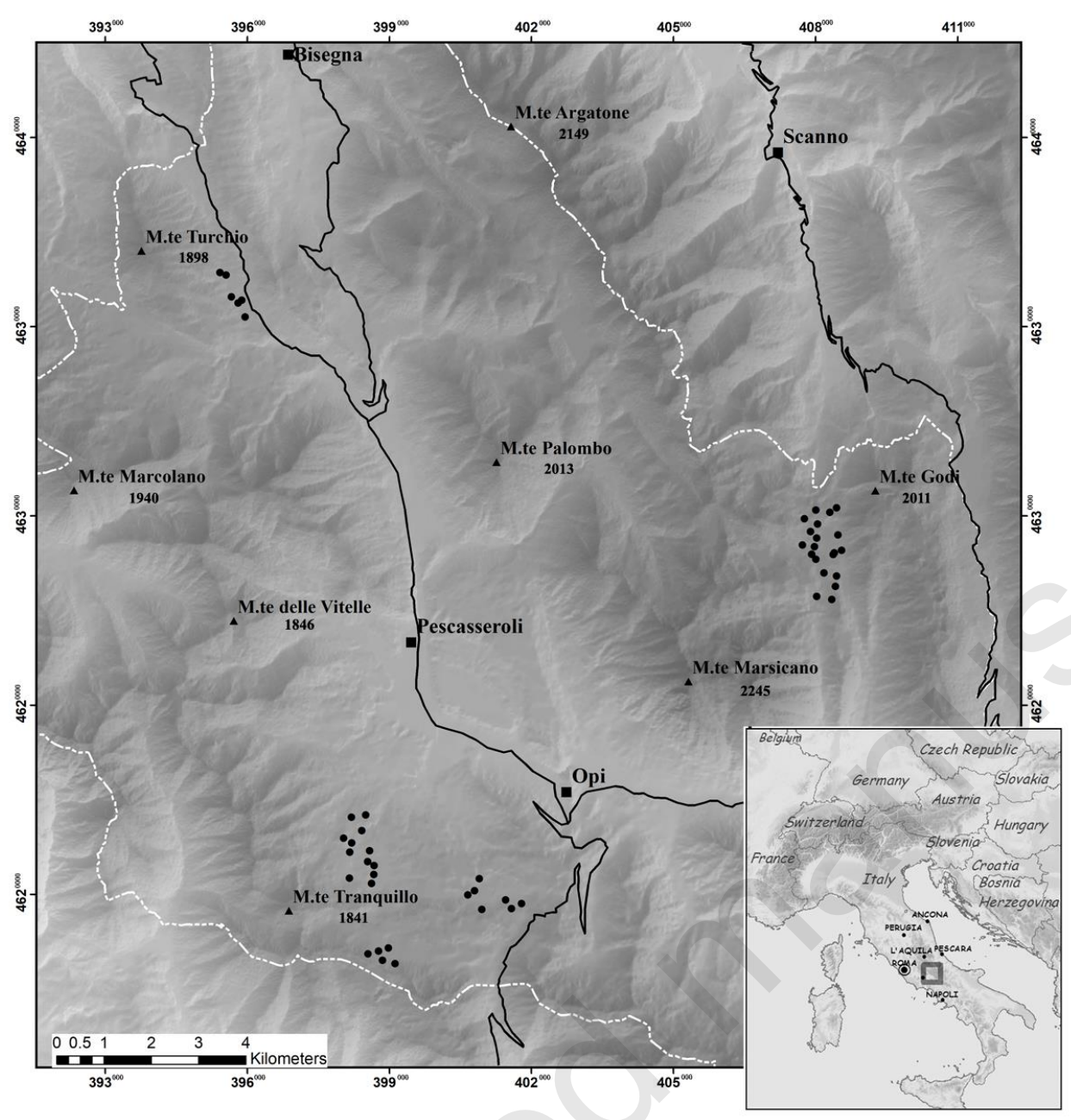

863 Fig. 1 Study area position (empty square in the inset) and distribution of sampling points (black dots in the 864 main map). Legend of main map: black lines: roads; white broken line: borders of Abruzzo Lazio \& Molise 865 National Park; filled squares: towns; filled triangles: main mountain peaks (with elevation, $\mathrm{m}$ a.s.I.) 


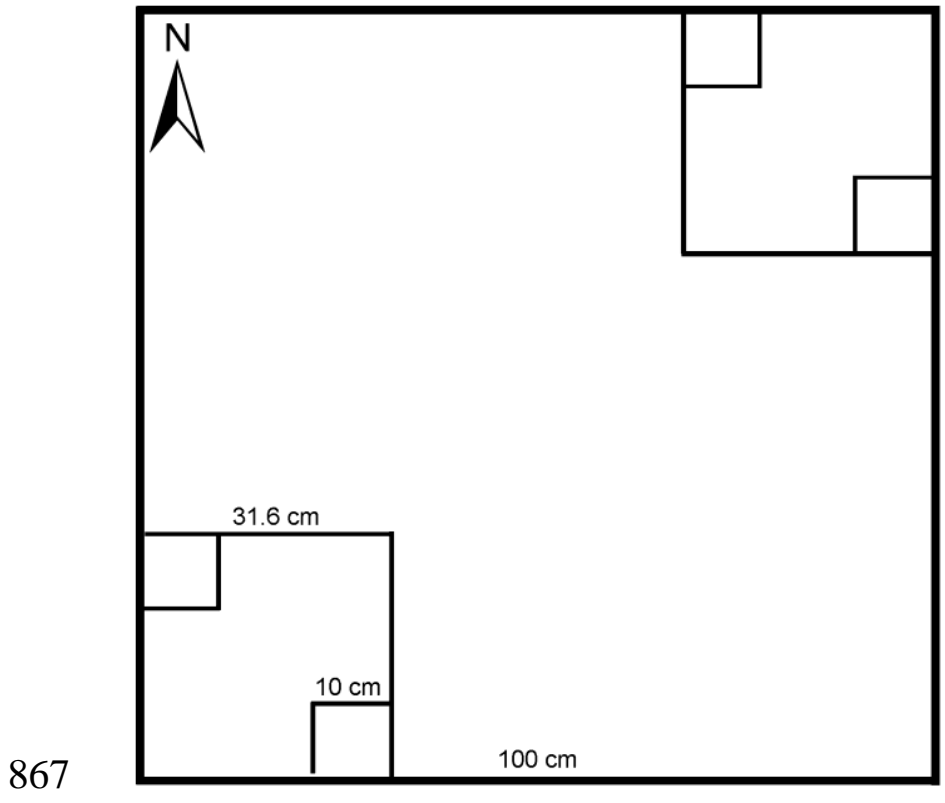

868 Fig. 2 Layout of the nested-plot series surveyed at each random sampling point. 869 


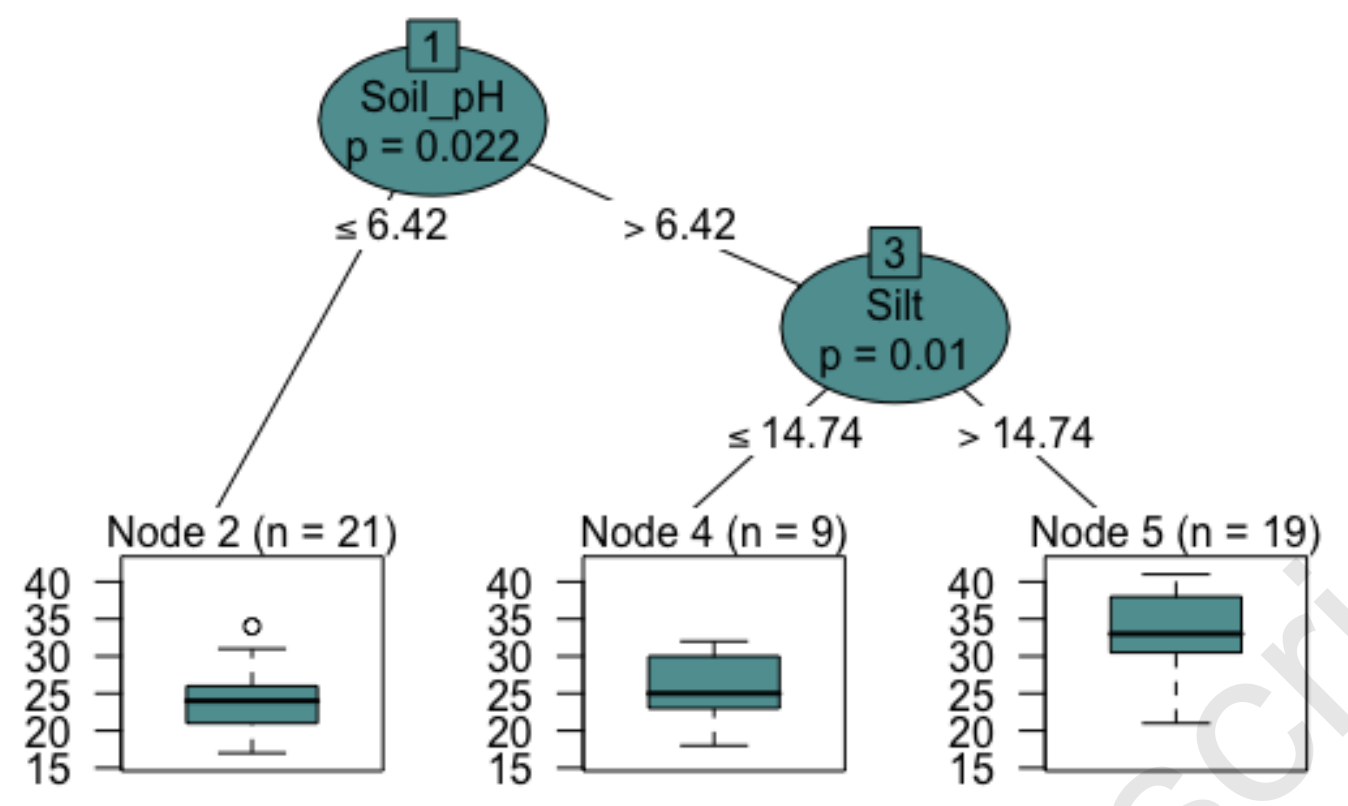

870

871 Fig. 3 Regression Tree for $1 \mathrm{~m}^{2}$ alpha-diversity as response variable. Variables responsible for tree splitting 872 are indicated in circles, with associated $p$-values. For each node, threshold values at which the observations 873 are split in groups are reported on the tree branches. For each terminal node (cluster of observations), the 874 boxplot describes the distribution of the response variable. On top of each boxplot, the number of 875 observations $(\mathrm{n})$ in the group is reported 


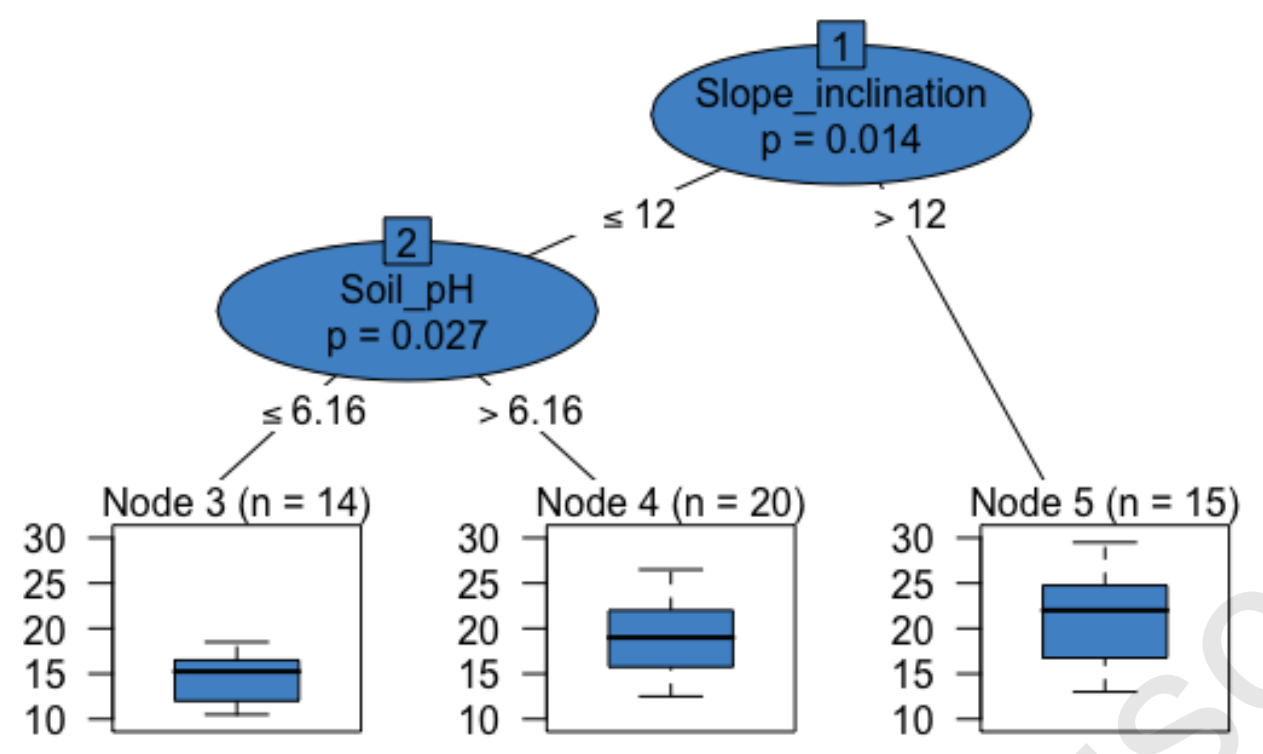

878

879 Fig. 4 Regression Tree for $0.1 \mathrm{~m}^{2}$ alpha-diversity as response variable. See caption in Fig. 3 for explanations.

880 Unlike the tree for $1 \mathrm{~m}^{2}$, here "univariate $\mathrm{p}$-values" (instead of Bonferroni-corrected) was set as stopping 881 rule

882 


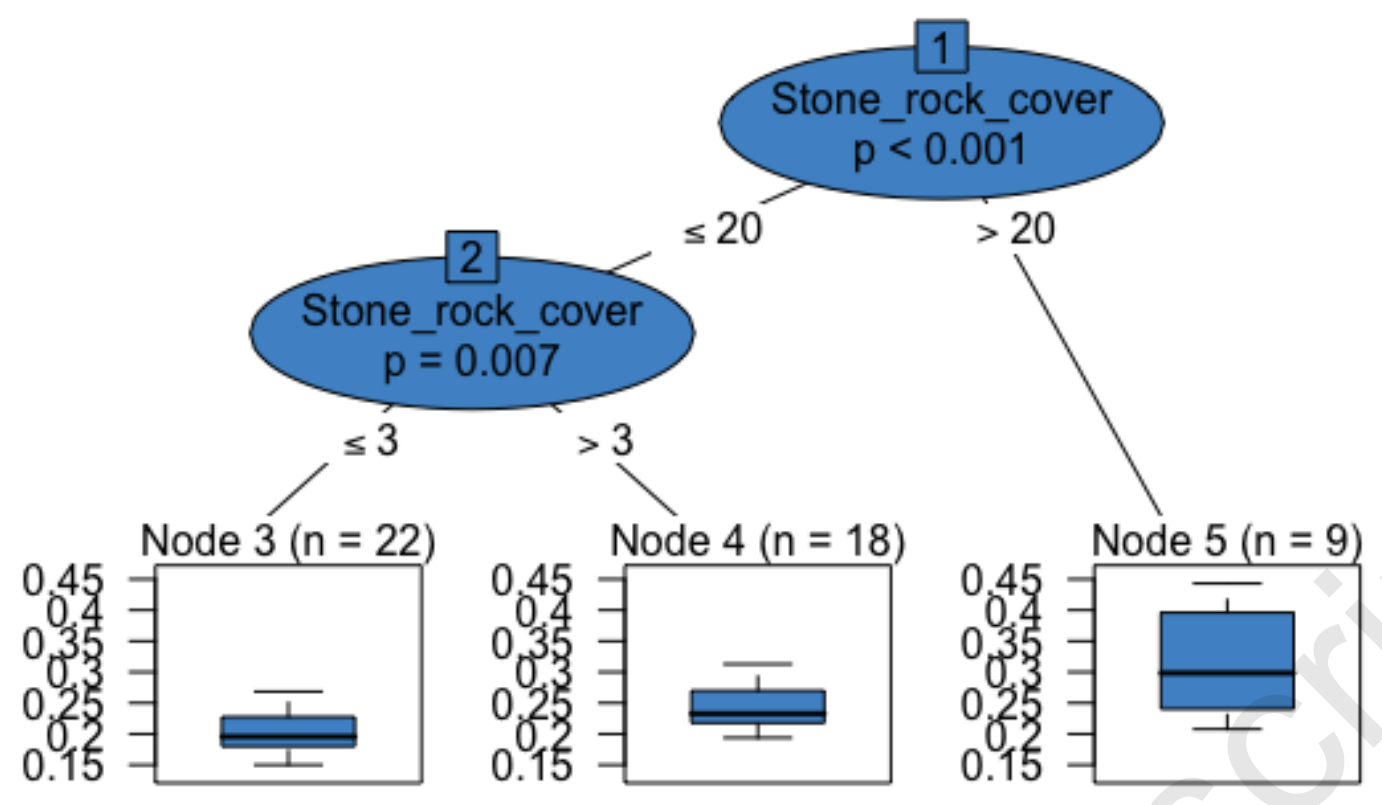

883

884 Fig. 5 Regression Tree for z-value as response variable. See caption in Fig. 3 for explanations 885

886 
888

\section{Continuous variables}

Elevation (m)

Slope inclination $\left(^{\circ}\right)$

Heat-load index

Soil depth (median) (cm)

Stone and rock cover (\%)

Soil $\mathrm{pH}$

Silt (\%)

Clay (\%)

Sand (\%)

Soil organic matter (\%)

\section{Categorical variables}

Land-form position (number of cases in each category)

$\begin{array}{cccc}\text { Mean } & \text { SD } & \text { Min. } & \text { Max. } \\ 1523 & 138 & 1331 & 1767 \\ 10.3 & 8.5 & 0 & 35 \\ 0.9 & 0.1 & 0.57 & 1.04 \\ 20.7 & 13.4 & 4 & 60 \\ 10.3 & 11.9 & 0 & 40 \\ 6.5 & 0.7 & 4.9 & 7.6 \\ 20.2 & 12.1 & 0 & 68.5 \\ 14 & 7.7 & 0.06 & 41 \\ 65.9 & 16.5 & 3.3 & 89.8 \\ 12.08 & 5.4 & 0.21 & 21.5\end{array}$

890 Tab. 1 Summary statistics of the environmental variables measured at each nested-plot series and used as

891 predictor variables in the statistical analysis 


\begin{tabular}{|l|l|l|l|l|l|}
\hline \multicolumn{7}{|c|}{ Species richness values } \\
\hline Area $\left(\mathrm{m}^{2}\right)$ & $n$ & Mean $\pm S D$ & Median & Min & Max \\
\hline 1 & 50 & $28.0 \pm 6.38$ & 27 & 17 & 41 \\
\hline 0.1 & 100 & $18.46 \pm 5.03$ & 17 & 9 & 31 \\
\hline 0.01 & 200 & $10.26 \pm 3.48$ & 10 & 0 & 20 \\
\hline \multicolumn{7}{|c|}{ Diversity metrics } \\
\hline Name & $n$ & Mean $\pm S D$ & Median & Min & Max \\
\hline $1 \mathrm{~m}^{2}$ alpha-diversity & 50 & $28.0 \pm 6.38$ & 27 & 17 & 41 \\
\hline $\begin{array}{l}0.1 \mathrm{~m}^{2} \text { average alpha- } \\
\text { diversity }\end{array}$ & 50 & $18.46 \pm 4.79$ & 17 & 10.5 & 29.5 \\
\hline $\begin{array}{l}0.01 \mathrm{~m}^{2} \text { average alpha- } \\
\text { diversity }\end{array}$ & 50 & $10.26 \pm 2.87$ & 10 & 4.5 & 16.25 \\
\hline z-value & 50 & $0.238 \pm 0.063$ & 0.224 & 0.150 & 0.443 \\
\hline
\end{tabular}

895 Tab.2 Summary statistics of the vascular plant richness encountered in all plots at different scales, and of

896 the derived biodiversity metrics used as dependent variables in the statistical analysis 
Taxon

Hieracium pilosella

Cerastium tomentosum

Festuca circummediterranea

Veronica arvensis

Euphrasia stricta

Trifolium repens

Achillea millefolium subsp. millefolium

Viola eugeniae

Bunium bulbocastanum

Poa alpina subsp. alpina

Medicago lupulina

Arenaria serpyllifolia subsp. serpyllifolia

Bellis perennis

Koeleria lobata

Avenula praetutiana

Dactylis glomerata

Potentilla rigoana
Frequency

$(n=50)$

$80 \%$

$76 \%$

$76 \%$

$74 \%$

$72 \%$

$68 \%$

$64 \%$

$64 \%$

$62 \%$

$62 \%$

$60 \%$

$58 \%$

$56 \%$

$56 \%$

$50 \%$

$50 \%$

$50 \%$

900

901 Tab.3 Most common species in the sample, and their frequency expressed as percentage of plots. Only the

902 species occurring in at least $50 \%$ of the plots are shown; see Online Resource 3 for full species list and

903 frequency values

904 


\begin{tabular}{|c|c|c|c|c|c|c|c|c|c|c|c|c|c|c|}
\hline & $\begin{array}{l}\frac{m}{\frac{m}{0}} \\
\frac{0}{0} \\
\frac{\overline{0}}{3}\end{array}$ & 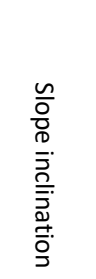 & 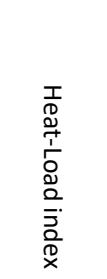 & 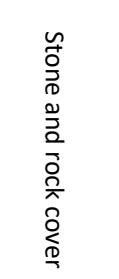 & 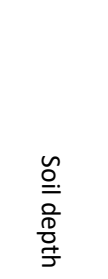 & $\stackrel{\frac{一}{2}}{\stackrel{2}{2}}$ & $\stackrel{\varrho}{\equiv}$ & $\frac{\widetilde{a}}{a}$ & 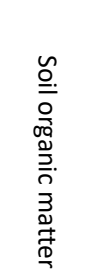 & 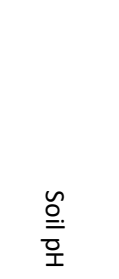 & 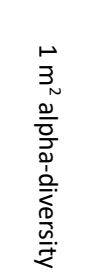 & 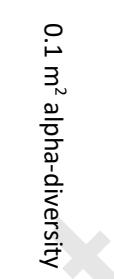 & 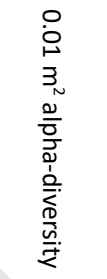 & 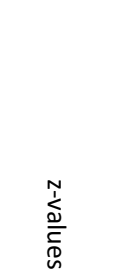 \\
\hline Elevation & & 0.002 & 0.0406 & 0.0001 & 0.3229 & 0.5566 & 0.8269 & 0.7875 & 0.1089 & $<0.0001$ & 0.1496 & 0.1043 & 0.6268 & 0.4198 \\
\hline Slope inclination & 0.425 & & 0.0064 & $<0.0001$ & 0.0838 & 0.1252 & 0.0553 & 0.0424 & 0.0700 & 0.0004 & 0.0987 & 0.0600 & 0.7375 & 0.0231 \\
\hline Heat-Load index & -0.291 & -0.380 & & 0.0888 & 0.7618 & 0.2853 & 0.4740 & 0.4275 & 0.1519 & 0.4418 & 0.3290 & 0.5415 & 0.9119 & 0.1512 \\
\hline Stone and rock cover & 0.537 & 0.562 & -0.243 & & 0.0007 & 0.0375 & 0.8169 & 0.4132 & 0.0325 & $<0.0001$ & 0.0167 & 0.0947 & 0.5773 & $<0.0001$ \\
\hline Soil depth & -0.143 & -0.247 & 0.044 & -0.464 & & 0.8117 & 0.6150 & 0.6368 & 0.3589 & $<0.0001$ & 0.1114 & 0.7386 & 0.3567 & 0.0005 \\
\hline Clay & -0.085 & -0.220 & 0.154 & -0.295 & -0.035 & & 0.4055 & 0.0001 & 0.0849 & 0.4342 & 0.2178 & 0.3512 & 0.4836 & 0.1790 \\
\hline Silt & 0.032 & -0.273 & 0.104 & -0.034 & 0.073 & 0.120 & & $<0.0001$ & 0.0310 & 0.5116 & 0.0329 & 0.0729 & 0.0775 & 0.9096 \\
\hline Sand & 0.039 & 0.288 & -0.115 & 0.118 & -0.068 & -0.530 & -0.868 & & 0.0207 & 0.1899 & 0.2058 & 0.2712 & 0.2725 & 0.6742 \\
\hline Soil organic matter & 0.229 & 0.258 & -0.206 & 0.303 & -0.133 & -0.246 & -0.305 & 0.326 & & 0.0016 & 0.3513 & 0.2896 & 0.5206 & 0.6732 \\
\hline Soil pH & 0.590 & 0.481 & -0.111 & 0.642 & -0.611 & -0.113 & -0.095 & 0.189 & 0.435 & & 0.0063 & 0.0309 & 0.4272 & 0.0314 \\
\hline $1 \mathrm{~m}^{2}$ alpha-diversity & 0.207 & 0.236 & -0.141 & 0.337 & -0.228 & -0.177 & 0.302 & -0.182 & 0.135 & 0.381 & & $<0.0001$ & $<0.0001$ & 0.1323 \\
\hline $0.1 \mathrm{~m}^{2}$ alpha-diversity & 0.232 & 0.268 & -0.088 & 0.239 & -0.048 & -0.135 & 0.256 & -0.159 & 0.153 & 0.306 & 0.877 & & $<0.0001$ & 0.6193 \\
\hline $1 \mathrm{~m}^{2}$ alpha-diversity & 0.070 & 0.049 & 0.016 & -0.081 & 0.133 & -0.101 & 0.252 & -0.158 & 0.093 & 0.115 & 0.702 & 0.844 & & 0.0002 \\
\hline$z$-values & 0.117 & 0.321 & -0.206 & 0.579 & -0.477 & -0.193 & -0.016 & 0.061 & 0.061 & 0.305 & 0.216 & -0.072 & -0.502 & \\
\hline
\end{tabular}

907 Tab.4 Pair-wise correlation table between all predictor and dependent variables. Below the diagonal:

908 Spearman's correlation coefficients $\left(r_{s}\right)$. Above the diagonal (in italic): $p$-values. Note that these are not

909 corrected for multiple testing. Correlation coefficients corresponding to a $p$-value $<0.05$ are in bold 


\begin{tabular}{|lcccc|}
\hline & $\begin{array}{c}1 \mathrm{~m}^{2} \text { alpha- } \\
\text { diversity }\end{array}$ & $\begin{array}{c}0.1 \mathrm{~m}^{2} \text { alpha- } \\
\text { diversity }\end{array}$ & $\begin{array}{c}0.01 \mathrm{~m}^{2} \text { alpha- } \\
\text { diversity }\end{array}$ & z-values \\
\hline Soil $\mathrm{pH}$ & 10 & 10 & 10 & 0 \\
\hline Silt & 10 & 10 & 10 & 0 \\
\hline Stone and rock cover & 10 & 10 & 0 & 10 \\
\hline Slope inclination & 9 & 10 & 0 & 10 \\
\hline Soil depth & 10 & 0 & 2 & 10 \\
\hline Land-form position & 10 & 0 & 0 & 10 \\
\hline Clay & 8 & 9 & 0 & 0 \\
\hline Soil organic matter & 0 & 1 & 1 & 0 \\
\hline Heat-load index & 0 & 0 & 0 & 0 \\
\hline
\end{tabular}

912

913 Tab. 5 Number of times, out of 10 Random Forest tries, that each predictor variable turned out to be

914 important for each dependent variable, i.e. featured positive values exceeding the absolute value of the

915 most negative score. Variables are listed in decreasing order of number of significant results 


\begin{tabular}{lcccr}
\hline & Stand. Coef. & Std. Error & $\mathbf{z}$ & p \\
\hline $\begin{array}{l}\text { Land-form: } \\
\text { hollow vs. hump }\end{array}$ & 0.161 & 0.076 & 2.12 & 0.034 \\
\hline Silt (\%) & 0.128 & 0.028 & 4.61 & $<0.0001$ \\
\hline Soil pH & 0.054 & 0.033 & 1.63 & 0.104 \\
\hline Slope inclination & 0.052 & 0.037 & 1.42 & 0.155 \\
\hline Clay (\%) & -0.040 & 0.029 & -1.39 & 0.166 \\
\hline $\begin{array}{l}\text { Land-form: } \\
\text { hollow vs. hillside }\end{array}$ & -0.011 & 0.087 & -0.13 & 0.897
\end{tabular}

918

919

920

921

$0.1 \mathrm{~m}^{2}$ alpha-diversity

\begin{tabular}{lrrrr}
\hline & Stand. Coef. & Std. Error & $\mathbf{t}$ & $\mathbf{p}$ \\
\hline Silt (\%) & 0.471 & 0.124 & 3.81 & $<0.001$ \\
\hline Slope inclination & 0.226 & 0.140 & 1.62 & 0.113 \\
\hline Soil pH & 0.220 & 0.134 & 1.64 & 0.109 \\
\hline Clay (\%) & -0.156 & 0.129 & -1.21 & 0.233 \\
\hline & & & & Adjusted $\mathbf{R}^{2}=\mathbf{0 . 3 1}$ \\
\hline
\end{tabular}

$0.01 \mathrm{~m}^{2}$ alpha-diversity

\begin{tabular}{lrrrr} 
& Stand. Coef. & Std. Error & $\mathbf{t}$ & $\mathbf{p}$ \\
\hline Silt (\%) & 0.370 & 0.135 & 2.75 & 0.009 \\
\hline Soil pH & 0.176 & 0.135 & 1.31 & 0.198 \\
\hline & & & & ${\text { Adjusted } \mathbf{R}^{2}=\mathbf{0 . 1 3}}$
\end{tabular}

Z-values

Stand. Coef.

\begin{tabular}{lcccr}
\hline Stone and rock cover & 0.627 & 0.136 & 4.62 & $<0.0001$ \\
\hline $\begin{array}{l}\text { Land-form: } \\
\text { hollow vs. hillside }\end{array}$ & 0.503 & 0.328 & 1.53 & 0.133 \\
\hline Slope inclination & -0.268 & 0.147 & -1.82 & 0.076 \\
\hline Soil depth & -0.247 & 0.120 & -2.06 & 0.045 \\
\hline $\begin{array}{l}\text { Land-form: } \\
\text { hollow vs. hump }\end{array}$ & 0.047 & 0.300 & 0.16 & 0.877
\end{tabular}

Adjusted $\mathrm{R}^{2}=0.47$

931 Tab. 6 Results of the Poisson GLM (for $1 \mathrm{~m}^{2}$ alpha-diversity) and of the Linear Models (for the remainder of

932 the response variables), after variable selection based on Random Forest outputs. Within each model, 
933 predictor variables are listed in order of decreasing (standardized) effect size. Stand. Coef. = Standardized

934 Coefficient; Std. Error = Standard Error of the coefficients

935 